\title{
Carriers for metal complexes on tumour cells: the effect of cyclodextrins vs CNTs on the model guest phenanthroline-5,6-dione trithiacyclononane ruthenium(II) chloride
}

\author{
Susana S. Braga $\cdot$ Joana Marques $\cdot$ Elena Heister • \\ Cátia V. Diogo • Paulo J. Oliveira • Filipe A. Almeida Paz • \\ Teresa M. Santos $\cdot$ Maria Paula M. Marques
}

Received: 7 January 2014/ Accepted: 28 February 2014/Published online: 21 March 2014

(C) Springer Science+Business Media New York 2014

\begin{abstract}
The complex $\left[\mathrm{Ru}[9] \mathrm{aneS}_{3}(\right.$ pdon) $\mathrm{Cl}] \mathrm{Cl}$ (pdon $=1,10$-phenanthroline-5,6-dione) was readily obtained from the stoichiometric reaction of $\mathrm{Ru}[9] \mathrm{a}-$ $\mathrm{neS}_{3}(\mathrm{dmso}) \mathrm{Cl}_{2}$ with pdon. Recrystallisation in ethanol using salicylic acid as a co-crystallisation helper afforded single-crystals suitable for the collection of X-ray diffraction data which afforded a reasonable structural description. Two different kinds of molecular carriers were tested as vehicles for this complex: carbon nanotubes (CNTs) and cyclodextrins. CNTs had an insufficient loading rate for the ruthenium complex at CNT concentrations deemed non-cytotoxic on cultured cells. The cyclodextrin (CD) carriers, $\beta-C D$ and TRIMEB (standing for permethylated $\beta-C D)$, were able to form two adducts, studied by
\end{abstract}

Electronic supplementary material The online version of this article (doi:10.1007/s10534-014-9725-8) contains supplementary material, which is available to authorized users.

S. S. Braga $(\bowtie) \cdot J$. Marques

Department of Chemistry, QOPNA Research Unit,

University of Aveiro, 3810-193 Aveiro, Portugal

e-mail: sbraga@ua.pt

E. Heister

Faculty of Health and Medical Sciences, University of

Surrey, Guildford GU2 7XH, UK

C. V. Diogo - P. J. Oliveira

CNC - Center for Neuroscience and Cell Biology,

Largo Marquês de Pombal, University of Coimbra,

3004-517 Coimbra, Portugal powder X-ray diffraction, thermogravimetric analysis (TGA), ${ }^{13} \mathrm{C}\left\{{ }^{1} \mathrm{H}\right\}$ CP/MAS NMR and FT-IR spectroscopies. The DNA thermal denaturation studies showed that the complex $\mathbf{1}$ is able to intercalate with DNA. The in vitro cytotoxicity of the free complex [Ru[9]a$\mathrm{neS}_{3}$ (pdon) $\left.\mathrm{Cl}\right] \mathrm{Cl}$ (1) and of its two CD adducts ( 2 and 3) was assessed on both rodent and human cell lines. By using the mouse K1735-M2 melanoma cell line and the non-tumour rat $\mathrm{H} 9 \mathrm{c} 2$ cardiomyoblasts, the results showed that $\mathbf{1}$ and $\mathbf{2}$ significantly inhibited the growth of the tumour cell line while displaying a good safety profile on cardiomyoblasts. Compound $\mathbf{3}$ at $100 \mu \mathrm{M}$ inhibited the proliferation of both cell lines, with a higher activity towards the melanoma cell line. The cytotoxicity of the compounds 1-3 was further assessed on human breast cancer cell lines. Against the MDA-MB-231 line, growth inhibition occurred only with $\mathbf{1}$ and $\mathbf{3}$ at the incubation time of $96 \mathrm{~h}$, both with

\author{
F. A. A. Paz - T. M. Santos \\ CICECO and Department of Chemistry, University of \\ Aveiro, 3810-193 Aveiro, Portugal \\ M. P. M. Marques \\ Molecular Physical-Chemistry R\&D Group and \\ Department of Life Sciences, Faculty of Science and \\ Technology, University of Coimbra, PO Box 3046, \\ 3001-401 Coimbra, Portugal
}


approximate inhibition rates of $50 \%$; against the MCF-7 line, mild cytotoxicity was observed at $48 \mathrm{~h}$ of incubation, with $\mathrm{IC}_{50}$ values calculated above $100 \mu \mathrm{M}$ for $\mathbf{1}, \mathbf{2}$ and $\mathbf{3}$.

Keywords Ruthenium complexes . 1,10-Phenanthroline-5,6-dione · Cyclodextrins . Cytotoxicity $\cdot$ Carbon nanotubes

\begin{tabular}{|c|c|}
\hline \multicolumn{2}{|l|}{ Abbreviations } \\
\hline$[9] \mathrm{aneS}_{3}$ & 1,4,7-Trithiacyclononane \\
\hline ANOVA & Analysis of variance \\
\hline $\mathrm{CD}$ & Cyclodextrin \\
\hline CNT & Carbon nanotube \\
\hline CP/MAS & $\begin{array}{l}\text { Cross-polarisation with magic- } \\
\text { angle spinning }\end{array}$ \\
\hline DMEM & $\begin{array}{l}\text { Dulbecco's modified eagle's } \\
\text { medium }\end{array}$ \\
\hline dmso & Dimethylsulfoxide \\
\hline DNA & Deoxyribonucleic acid \\
\hline dppz & Dipyrido $\left[3,2-a: 2^{\prime}, 3^{\prime}-c\right]$ phenazine \\
\hline EDTA & Ethylenediaminetetraacetic acid \\
\hline EAT & Ehrlich ascites tumour \\
\hline EtOH & Ethanol \\
\hline FBS & Fetal bovine serum \\
\hline FT-IR & $\begin{array}{l}\text { Fourier-transform infrared } \\
\text { spectroscopy }\end{array}$ \\
\hline $\mathrm{H} 9 \mathrm{c} 2$ & $\begin{array}{l}\text { Non-tumoural H9c2 cardiomyoblast } \\
\text { cell line }\end{array}$ \\
\hline $\mathrm{IC}_{50}$ & $\begin{array}{l}\text { Half maximal inhibitory } \\
\text { concentration }\end{array}$ \\
\hline K1735-M2 & Mouse melanoma cell line \\
\hline MCF-7 & $\begin{array}{l}\text { Human epithelial breast } \\
\text { adenocarcinoma cell line (estrogen } \\
\text { dependent) }\end{array}$ \\
\hline MDA-MB-231 & $\begin{array}{l}\text { Human epithelial breast } \\
\text { adenocarcinoma cell line (estrogen } \\
\text { independent) }\end{array}$ \\
\hline MTT & $\begin{array}{l}\text { 3-[4,5-Dimethylthiazol-2-yl]-2,5- } \\
\text { diphenyltetrazolium bromide }\end{array}$ \\
\hline NMR & Nuclear magnetic resonance \\
\hline oxCNT & Oxidised carbon nanotube \\
\hline PBS & Phosphate buffered saline \\
\hline phen & 1,10-Phenanthroline \\
\hline pdon & 1,10-Phenanthroline-5,6-dione \\
\hline SRB & Sulforhodamine B \\
\hline TGA & Thermogravimetric analysis \\
\hline XRD & $\mathrm{X}$-ray diffraction \\
\hline
\end{tabular}

\section{Introduction}

The past years have witnessed a variety of new materials emerging as drug carriers or delivery systems, including inorganic nanoparticles (Allen and Cullis 2004; Barroug and Glimcher 2002; Chen et al. 2004; Lin et al. 2002; Radin et al. 2001; Roy et al. 2003) and carbon nanotubes (CNTs). In parallel, there was an expansion in the number of both marketed products and formulations undergoing clinical tests which contain the traditional organic nano-scale carriers: liposomes (Roseanu et al. 2010), micelles (Wagner and Vorauer-Uhl 2011; Parveen et al. 2012) and cyclodextrins (CDs) (Szejtli 1998). CDs are found in commercial drugs as solubilisers or formulation helpers for different active pharmaceutical ingredients, from anti-inflammatory agents (e.g. nimesulide, diclofenac, indometacin, meloxicam, tiaprofenic acid) to anti-septics (cloranfenicol, mitomycin, cephalosporin), anti-maniac agents, nicotine, prostaglandins and others (Davis and Brewster 2004). In our group, the formation of solid $\beta-C D$ inclusion compounds with ibuprofen, nimesulide and omeprazole was studied (Braga et al. 2003a, b, c). Recently, we focused on the carrier and activity-enhancing properties of CDs in a collection of cytotoxic metal coordination compounds, but we were unable to establish a general trend for the carrier effect, since the effect of CDs upon the guest's cytotoxic activity was shown to vary from one case to the next. For instance, the TRIMEB inclusion compound with the bactericidal $\left[\mathrm{Ru}\left([9] \mathrm{aneS}_{3}\right)\right.$ (phen) $\mathrm{Cl}] \mathrm{Cl}$ afforded higher activity (Marques et al. 2009a) whereas the cytotoxicity was lower in the inclusion compound of $\beta-\mathrm{CD}$ with the bioinorganic complex $\left[\mathrm{Ru}\left([9] \mathrm{aneS}_{3}\right)(\right.$ glycine $\left.) \mathrm{Cl}\right] \mathrm{Cl}$; at $72 \mathrm{~h}$ of incubation, the compound of $\beta-\mathrm{CD}$ with the ruthenium glycine complex guest only displayed mild inhibition of the osteosarcoma MG-63 line (Marques et al. 2009b). The organometallic iron compound trimethyl(ferrocenylmethyl)ammonium iodide, cytotoxic against the breast cancer MDA-MB-231 line at $48 \mathrm{~h}$ of incubation, showed a very slight increase in the activity upon inclusion into $\beta$-CD (Bruno et al. 2011).

The present work focuses on two kinds of noncovalent carriers, cyclodextrins and CNTs, which form supramolecular interactions with their guests. The complex $\left[\mathrm{Ru}\left([9] \mathrm{aneS}_{3}\right)(\right.$ pdon$\left.) \mathrm{Cl}\right] \mathrm{Cl}(\mathbf{1})$, containing the aromatic heterocyclic ligand phenanthroline- 
5,6-dione (pdon), was chosen as a model guest. The $o$ quinone moiety in this ligand has $\mathrm{pH}$-dependent electroactivity (Goss and Abruña 1985) enabling it to function as a "quinone equivalent" (Brechin et al. 2008 ) in its $N, N^{\prime}$-coordinated metal complexes. Pdon is highly cytotoxic on a number of cancer cell lines, with $\mathrm{IC}_{50}$ values starting at 0.6 micromolar on the MCF-7 line, for instance (Roy et al. 2008), and forms cytotoxic complexes with a few metals, including $\mathrm{Ag}(\mathrm{II}), \mathrm{Cu}$ (II) (Deegan et al. 2006), Pt(II) (Roy et al. 2008, Dikmen et al. 2011) and Ru (Alanyali et al. 2011). The complex $\left[\mathrm{Ru}\left([9] \mathrm{aneS}_{3}\right)(\right.$ pdon) $\mathrm{Cl}] \mathrm{Cl}$ (1) is thus expected to display cytotoxicity. The implications of the cyclodextrin carriers on the biological activity of 1 will be studied by evaluating the cytotoxicity of its adducts with $\beta-C D$ and TRIMEB against rodent and human tumour cell lines.

In this work, CNTs are also tested as non-covalent carriers for the complex $\mathbf{1}$, given that these may pose as a suitable alternative to cyclodextrins. Indeed, CNTs are promising carriers within the emerging nanomaterials for drug delivery due to their high surface area-to-volume ratio which allows them to load significant amounts of drug. There are different mechanisms for the loading process. (i) Guest molecules are attached to the surface by means of electrostatic, hydrophobic and $\pi-\pi$ interactions. (ii) Guests are attached to the surface by a biocompatible linker, owing to ease of chemical functionalisation of the surface of CNTs; literature examples include amphotericin B (Wu et al. 2005), paclitaxel (Huang et al. 2011), doxorubicin (Ali-Boucetta et al. 2008; Heister et al. 2012), cisplatin (Hilder and Hill 2008), and even plasmid DNA. (iii) Guest molecules of appropriate size are contained in the hollow interior of CNTs, after opening of the end caps; in this situation the CNTs may also exhibit sustained release activity, as reported with carboplatin (Arlt et al. 2010) and cisplatin (Guven et al. 2012).

\section{Experimental section}

Materials and methods

$\beta$-CD was kindly donated by laboratoires La Roquette (Lestrem, France). 2,3,6-tris-O-methyl- $\beta$-CD (TRIMEB), the single-walled CNTs SWeNT ${ }^{\circledR}$ SG 65 (Lot No. MKBB63098), the calf thymus DNA (ct-DNA) and all of the other chemicals were purchased from Sigma-Aldrich. The nanotubes were originally produced by SouthWest NanoTechnologies by the CoM$\mathrm{oCAT}^{\circledR}$ method. Tube diameters are $0.8 \pm 0.1 \mathrm{~nm}$, carbon content is $>90 \%$ by weight, $>50 \%$ of tubes are $(6,5)$ chirality, and $>90 \%$ of tubes semiconducting. 4-arm, amine terminated (branched PEG 2500- $\mathrm{NH}_{2}$, from Sigma-Aldrich, Poole, UK). All air-sensitive operations were carried out using standard Schlenk techniques under argon. Solvents were dried by standard procedures and kept over 4 Å molecular sieves.

Microanalyses were performed at the Department of Chemistry, University of Aveiro, on an TruSpec 630-200-200 Elemental Analyser. Samples, weighing 1-5 mg, were combusted under an oxygen atmosphere at $1,075{ }^{\circ} \mathrm{C}$. Ru was determined by ICP-OES at the Central Laboratory for Analysis, University of Aveiro.

Powder X-ray diffraction data of the bulk compounds were collected at ambient temperature on a X'Pert MPD Philips diffractometer $\left(\mathrm{Cu} \mathrm{K} \alpha_{1,2}\right.$ X-radiation, $\lambda_{1}=$ $1.540598 \AA$ and $\lambda_{2}=1.544426 \AA$ ), equipped with a $\mathrm{X}$ 'Celerator detector and a flat-plate sample holder in a Bragg-Brentano para-focusing optics configuration (40 kV, $50 \mathrm{~mA})$. Intensity data were collected by the step-counting method (step $0.02^{\circ}$ ), in continuous mode, in the ca. $3.0^{\circ} \leq 2 \theta \leq 50.0^{\circ}$ range.

TGA studies were carried out using a Shimadzu TGA-50 system using a heating rate of $5{ }^{\circ} \mathrm{C} / \mathrm{min}$, under air atmosphere, with a flow rate of $20 \mathrm{~mL} / \mathrm{min}$. The sample holder was a $5 \mathrm{~mm} \varnothing$ platinum plate and the sample mass was typically 1 to $5 \mathrm{mg}$. The physical mixtures of cyclodextrin ( $\beta$-CD or TRIMEB) and the complex 1 were prepared by weighing masses corresponding to the equimolar proportions of each $\mathrm{CD}$ (white colour) and $\mathbf{1}$ (brown colour), placing the powders in a mortar and gently mixing them with the pestle over a few seconds until the colour of the mixture was perceived as homogenous.

FT-IR spectra (range $4,000-400 \mathrm{~cm}^{-1}$ ) were collected as $\mathrm{KBr}$ pellets using a Unican Mattson Mod 7000 FT-IR spectrophotometer by averaging 64 scans at a maximum resolution of $2 \mathrm{~cm}^{-1}$. In a typical preparation, $2 \mathrm{mg}$ of sample were mixed in a mortar with $200 \mathrm{mg}$ of $\mathrm{KBr}$. Raman spectra were recorded on a Bruker RFS/100S FT-Raman system, using a Nd:YAG $(1064 \mathrm{~nm})$ laser (50 $\mathrm{mW}$ at the sample position).

${ }^{13} \mathrm{C}\left\{{ }^{1} \mathrm{H}\right\}$ CP/MAS NMR spectra were recorded at $125.72 \mathrm{MHz}$ on a Bruker Avance 500 spectrometer, with an optimised $\pi / 2$ pulse for ${ }^{1} \mathrm{H}$ of $4.5 \mu \mathrm{s}, 2 \mathrm{~ms}$ 
contact time, a spinning rate of $7 \mathrm{kHz}$ and $12 \mathrm{~s}$ recycle delays. Chemical shifts are quoted in parts per million from tetramethylsilane.

UV/vis absorption spectra were collected using a Helios Alpha UV/Vis spectrophotometer from Thermo Scientific.

\section{Syntheses $\left[\mathrm{Ru}\left([9] \mathrm{aneS}_{3}\right)(\right.$ pdon$\left.) \mathrm{Cl}\right] \mathrm{Cl}(\mathbf{1})$}

This complex was prepared by adaptation of a literature procedure (Madureira et al. 2000). A solution of $\left.\mathrm{Ru}[9] \mathrm{aneS}_{3}\right)(\mathrm{dmso}) \mathrm{Cl}_{2}(107.5 \mathrm{mg}, 0.26 \mathrm{mmol})$ in ethanol (15 mL) was treated with solid 1,10-phenanthroline-5,6-dione $(54.5 \mathrm{mg}, 0.26 \mathrm{mmol})$ and stirred for $6 \mathrm{~h}$ at $80{ }^{\circ} \mathrm{C}$ under reflux. The resulting brown mixture was refrigerated to $5{ }^{\circ} \mathrm{C}$ overnight to promote precipitation of a golden brown microcrystalline solid. The solvent was decanted and the solid washed several times with dry diethyl ether to obtain the complex $\left[\mathrm{Ru}\left([9] \mathrm{aneS}_{3}\right)\right.$ (pdon)Cl]Cl. Yield: $111.5 \mathrm{mg}(68.8 \%)$.

Elemental Composition (in \%). Anal. Calc. for $\left(\mathrm{C}_{18} \mathrm{H}_{18} \mathrm{RuN}_{2} \mathrm{~S}_{3} \mathrm{O}_{2} \mathrm{Cl}_{2}\right) \cdot 2.5 \mathrm{H}_{2} \mathrm{O}$ (607.6): C, 35.58; $\mathrm{H}$, 3.81; N, 4.61; S, 15.83. Found: C, 35.18; H, 3.78; N, 3.95; S, 16.25 .

FT-IR $\left(\mathrm{KBr}, \mathrm{cm}^{-1}\right): 3352$ vs, $2924 \mathrm{~m}, 2903 \mathrm{sh}$, $1632 \mathrm{~m}, 1426 \mathrm{~m}, 1413 \mathrm{~m}, 1383 \mathrm{~m}, 1368 \mathrm{w}, 1334 \mathrm{~m}$, $1302 \mathrm{~m}, 1246 \mathrm{~m}, 1204 \mathrm{~m}, 1158 \mathrm{~s}, 1101 \mathrm{~s}, 1079 \mathrm{~s}$, 1054 vs, 1027 vs, $1002 \mathrm{~s}, 944 \mathrm{~m}, 938 \mathrm{~m}, 863 \mathrm{~m}$, $758 \mathrm{~m}, 702 \mathrm{~m}, 607 \mathrm{sh}, 587 \mathrm{sh}, 576 \mathrm{~m}, 529 \mathrm{~m}, 477 \mathrm{w}$, $445 \mathrm{w}, 414 \mathrm{w}, 360 \mathrm{~m}$. FT-Raman $\left(\mathrm{cm}^{-1}\right): 3391 \mathrm{w}$, 3275 w, 3109 s, 3076 m, 2946 vs, 2900 vs, 1460 s, $1411 \mathrm{~s}, 1382 \mathrm{~s}, 1328 \mathrm{~s}, 1264 \mathrm{~m}, 1247 \mathrm{~s}, 1140 \mathrm{~m}$, 1106 vs, $1088 \mathrm{~m}, 1043 \mathrm{~s}, 999 \mathrm{w}, 974$ w, $948 \mathrm{~m}$, $926 \mathrm{~m}, 869 \mathrm{~s}, 764 \mathrm{w}, 738 \mathrm{~m}, 708 \mathrm{w}, 648 \mathrm{w}, 619 \mathrm{w}$, 599 m, 576 m, 536 w, $501 \mathrm{~m}, 481 \mathrm{vs,}, 450$ m, $413 \mathrm{~m}$, $396 \mathrm{~m}, 357 \mathrm{~m}, 325 \mathrm{~s}, 312 \mathrm{~m}, 221 \mathrm{~m}$.

${ }^{13} \mathrm{C}\left\{{ }^{1} \mathrm{H}\right\}$ CP/MAS NMR: $\delta=172.2$ (pdon, CO), 157.2 (pdon, $\mathrm{C}-\mathrm{H}$ ), 153.7 (pdon, $>\mathrm{C}=$ ), 135.8 (pdon, $\mathrm{C}-\mathrm{H}$ ), 130.4 (pdon, $>\mathrm{C}=$ ), 125.7 (pdon, $\mathrm{C}-\mathrm{H}$ ), 41.2, 37.0, 33.1, 30.5, 25.9 (all from [9] $\mathrm{aneS}_{3}$ ) ppm. Assignment of pdon carbon resonances was made by reference to the reported solution spectrum of the ligand 1,10-phenanthroline-5,6-dione in deuterated dmso (Larsson and Öhrström 2004).

$\beta-\mathrm{CD} \cdot\left[\mathrm{Ru}\left([9] \mathrm{aneS}_{3}\right)(\mathrm{pdon}) \mathrm{Cl}\right] \mathrm{Cl}(\mathbf{2})$

Solid $\left[\mathrm{Ru}\left([9] \mathrm{aneS}_{3}\right)(\mathrm{pdon}) \mathrm{Cl}\right] \mathrm{Cl} \quad$ (1) $\quad(88.9 \mathrm{mg}$, $0.155 \mathrm{mmol}$ ) was added to a solution of $\beta-\mathrm{CD}$
(139.9 $\mathrm{mg}, 0.125 \mathrm{mmol})$ in water $(10 \mathrm{~mL})$ and the resultant brown solution was stirred for $10 \mathrm{~min}$ at room temperature (ca. $293 \mathrm{~K}$ ) and then immediately frozen using liquid nitrogen to prevent chloride hydrolysis. Water was removed by freeze-drying to obtain a voluminous brown solid.

Elemental Composition (in \%). Anal. Calc. for $\left(\mathrm{C}_{42} \mathrm{H}_{70} \mathrm{O}_{35}\right) \cdot\left(\mathrm{C}_{18} \mathrm{H}_{18} \mathrm{RuN}_{2} \mathrm{~S}_{3} \mathrm{O}_{2} \mathrm{Cl}_{2}\right) \cdot 14 \mathrm{H}_{2} \mathrm{O}$ (1948.4): C, 36.95; H, 6.00; N, 1.43; Ru, 5.23. Found: C, 36.64; $\mathrm{H}, 5.43$; N, 1.03; Ru, 5.76. TGA revealed a dehydration step of $15 \%$, corresponding to 13 water molecules.

FT-IR (KBr pellet; in $\mathrm{cm}^{-1}$ ): nu(tilde) $=3367 \mathrm{vs,}$ 2924 s, 1698 s, 1693 sh, 1638 m, 1571 sh, 1567 m, 1423 m, 1380 m, 1369 m, 1334 m, 1299 m, 1202 m, $1157 \mathrm{~s}, 1078 \mathrm{~s}, 1028$ vs, $1002 \mathrm{~s}, 947 \mathrm{~m}, 938 \mathrm{~m}$, $860 \mathrm{~m}, \quad 817 \mathrm{~m}, \quad 756 \mathrm{~m}, 708 \mathrm{~m}, 668 \mathrm{~m}, 609 \mathrm{~m}$, $578 \mathrm{~m}, 530 \mathrm{~m}, 389 \mathrm{w}, 361 \mathrm{w}$.

${ }^{13} \mathrm{C}\left\{{ }^{1} \mathrm{H}\right\}$ CP/MAS NMR: $\delta=161.1,156.2,136.0$, 128.9 (guest, pdon), 101.9, $101.8\left(\beta-\mathrm{CD}, \mathrm{C}_{1}\right)$, $81.0\left(\beta-C D, C_{4}\right), 72.8\left(\beta-C D, C_{2,3,5}\right), 59.7(\beta-C D$, $\mathrm{C}_{6}$ ), 36.5, 29.3 (guest, [9]aneS $\mathrm{S}_{3}$ ) ppm (see Scheme 1 below for the numbers attributed to the cyclodextrin carbons).

\section{TRIMEB·[Ru([9]aneS $\left.{ }_{3}\right)($ pdon$\left.) \mathrm{Cl}\right] \mathrm{Cl}(\mathbf{3})$}

A solution of TRIMEB (143 mg, $0.10 \mathrm{mmol})$ in a mixture of ethanol $(20 \mathrm{~mL})$ and acetone $(4 \mathrm{~mL})$ was treated with $\left[\mathrm{Ru}\left([9] \mathrm{aneS}_{3}\right)(\right.$ pdon$\left.) \mathrm{Cl}\right] \mathrm{Cl}(\mathbf{1})(57.2 \mathrm{mg}$, $0.10 \mathrm{mmol})$ in acetonitrile $(10 \mathrm{~mL})$; the resulting brown mixed solution was kept in a water bath at $30{ }^{\circ} \mathrm{C}(303 \mathrm{~K})$ and stirred for $180 \mathrm{~min}$. The solvent was then evaporated to yield a brown vitreous solid.

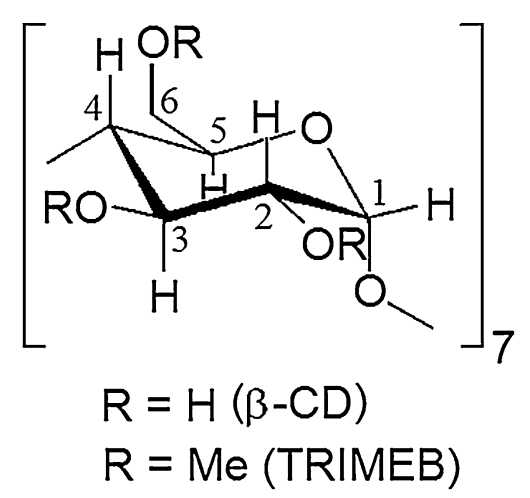

Scheme 1 Carbon numbering for $\beta$-CD and TRIMEB 
Elemental Composition (in \%). Anal. Calc. for $\left(\mathrm{C}_{63} \mathrm{H}_{112} \mathrm{O}_{35}\right) \cdot\left(\mathrm{C}_{18} \mathrm{H}_{28} \mathrm{RuN}_{2} \mathrm{~S}_{3} \mathrm{O}_{2} \mathrm{Cl}_{2}\right) \cdot 3 \mathrm{H}_{2} \mathrm{O}$ (2054.7): C, 47.30; H, 7.16; N, 1.36; Ru, 4.96. Found: C, 47.44; $\mathrm{H}, 6.41 ; \mathrm{N}, 1.22 ; \mathrm{Ru}, 5.47$. TGA up to $75^{\circ} \mathrm{C}$ revealed a sample weight loss of $1.0 \%$ (calculated for the loss of $2 \mathrm{H}_{2} \mathrm{O}, 1.6 \%$ ).

FT-IR $\left(K B r\right.$ pellet; in cm ${ }^{-1}$ ): 3062 w, 2976 m, 2929 s, $2833 \mathrm{~m}, 1691 \mathrm{~s}, 1567 \mathrm{~m}, 1464 \mathrm{~s}, 1449 \mathrm{~s}, 1422 \mathrm{~m}$, $1406 \mathrm{~m}, 1368 \mathrm{~m}, 1323 \mathrm{~m}, 1303 \mathrm{~m}, 1193 \mathrm{~s}, 1161 \mathrm{vs}$, 1142 vs, 1108 vs, 1090 vs, 1070 vs, 1038 vs, 970 s, 951 s, $940 \mathrm{sh}, 911 \mathrm{~m}, 856 \mathrm{~m}, 826 \mathrm{~m}, 814 \mathrm{~m}, 706 \mathrm{~m}, 565 \mathrm{~s}$, 554 m, 391 m, 364 m, 346 w, 339 w, 332 w, 320 w.

${ }^{13} \mathrm{C}\left\{{ }^{1} \mathrm{H}\right\}$ CP/MAS NMR: 171.6 (guest, CO), 156.9, 153.6, 135.6, 129.7, 125.9 (guest, pdon), 98.6 (TRIMEB, $\mathrm{C}_{1}$ ), 82.5 (TRIMEB, $\mathrm{C}_{2,3,4}$ ), 71.2 (TRIMEB, $\mathrm{C}_{5,6}$ ), 58.1 (TRIMEB, O- $\mathrm{CH}_{3}$ ), 40.8, 36.5, 33.0, 29.8, 25.8 (guest, [9]aneS ${ }_{3}$ ) ppm (see Scheme 1 below for numbering).

Single-crystal X-ray diffraction studies

A single-crystal obtained from the recrystallisation of the complex 1 with salycilic acid was mounted on a Hampton Research CryoLoop using FOMBLIN Y perfluoropolyether vacuum oil (LVAC 25/6) purchased from Aldrich (Kottke and Stalke 1993), with the help of a Stemi 2000 stereomicroscope equipped with Carl Zeiss lenses. Data were collected at 150(2) K on a Bruker X8 Kappa APEX II charge-coupled device (CCD) area-detector diffractometer (Mo $\mathrm{K}_{\alpha}$ graphitemonochromated radiation, $\lambda=0.71073 \AA$ ) controlled by the APEX2 software package (APEX2 2006), and equipped with an Oxford Cryosystems Series 700 cryostream monitored remotely using the software interface Cryopad (Cryopad 2006). Images were processed using the software package SAINT+ (SAINT+ 1997-2005), and data were corrected for absorption by the multi-scan semi-empirical method implemented in SADABS (Sheldrick 1998). The structure was solved by the direct methods of SHELXS-97 (Sheldrick 1997a, 2008), and refined by fullmatrix least squares on $F^{2}$ using SHELXL-97 (Sheldrick 1997b, 2008). All non-hydrogen atoms were directly located from difference Fourier maps and successfully refined with anisotropic displacement parameters. We note that the two charge-balancing chloride anions, one per each crystallographically independent $\left[\mathrm{Ru}\left([9] \mathrm{aneS}_{3}\right)(\text { pdon }) \mathrm{Cl}\right]^{+}$cation, have been found to be statistically disorder over five different crystallographic sites. These moieties have been included in the final structural model with a fixed rate of occupancy of $40 \%$ in each crystallographic position.

Hydrogen atoms bound to carbon were located at their idealised positions using appropriate HFIX instructions in SHELXL: 43 for the aromatic $-\mathrm{CH}$ and 23 for the $-\mathrm{CH}_{2}-$ moieties attached to the [9] aneS $\mathrm{S}_{3}$ organic ligands. All these atoms were included in subsequent refinement cycles in riding motion approximation with isotropic thermal displacements parameters $\left(U_{\text {iso }}\right)$ fixed at $1.2 \times U_{\text {eq }}$ of the parent carbon atoms.

A considerable smeared-out electron density was found in the empty spaces available in the crystal structure that prevented a sensible location and refinement of any solvent molecules. Searches for the total potential solvent area using the software package PLATON (Spek 1990, 2003) revealed the presence of a large cavity centred at $(0.030-0.078$ 1/2) with an internal volume of ca. $593 \AA^{3}$ (ca. $18 \%$ of the total volume of the unit cell). The original data set was then mathematically treated using the SQUEEZE (van der Sluis and Spek 1990) subroutines in order to remove the contribution of these highly disordered molecules in the solvent-accessible volume. It was estimated that the ca. $18 \%$ empty volume would contain ca. 318 electrons. The calculated solvent-free reflection list was then used for further structural refinement of the $\left[\mathrm{Ru}\left([9] \mathrm{aneS}_{3}\right)\right.$ (pdon) $\left.\mathrm{Cl}\right] \mathrm{Cl}$-(salycilic acid) $x$ (solvent) compound.

The last difference Fourier map synthesis showed the highest peak $\left(7.635 \mathrm{e}^{-3}\right)$ and deepest hole $\left(-1.526 \mathrm{e}^{-3}\right)$ located at 1.19 and $1.33 \AA$ from O9 and $\mathrm{O6}$, respectively. Information concerning crystallographic data collection and structure refinement details for the SQUEEZE data set of $\left[\mathrm{Ru}\left([9] \mathrm{aneS}_{3}\right)\right.$ (pdon) $\mathrm{Cl}] \mathrm{Cl} \cdot($ salycilic acid) $x$ (solvent) is summarised in Table 1. Geometrical parameters associated with the coordination environments of the two crystallographically independent $\mathrm{Ru}(\mathrm{II})$ metal centres are provided in Table 2. Structural drawings have been produced using the software package Crystal Diamond (Brandenburg 1997-2010).

Crystallographic data for the $\left[\mathrm{Ru}\left([9] \mathrm{aneS}_{3}\right)\right.$ (pdon) $\mathrm{Cl}] \mathrm{Cl} \cdot$ (salycilic acid) $x$ (solvent) crystalline structure have been deposited with the Cambridge Crystallographic Data Centre as supplementary publication No. CCDC-927998. Copies of the data can be obtained free of charge on application to CCDC, 12 Union Road, 
Table 1 Crystal and structure refinement data for the complex $\left[\mathrm{Ru}\left([9] \mathrm{aneS}_{3}\right)(\right.$ pdon$\left.) \mathrm{Cl}\right] \mathrm{Cl}$ (salycilic acid) $x$ (solvent) (data obtained using the SQUEEZE data set)

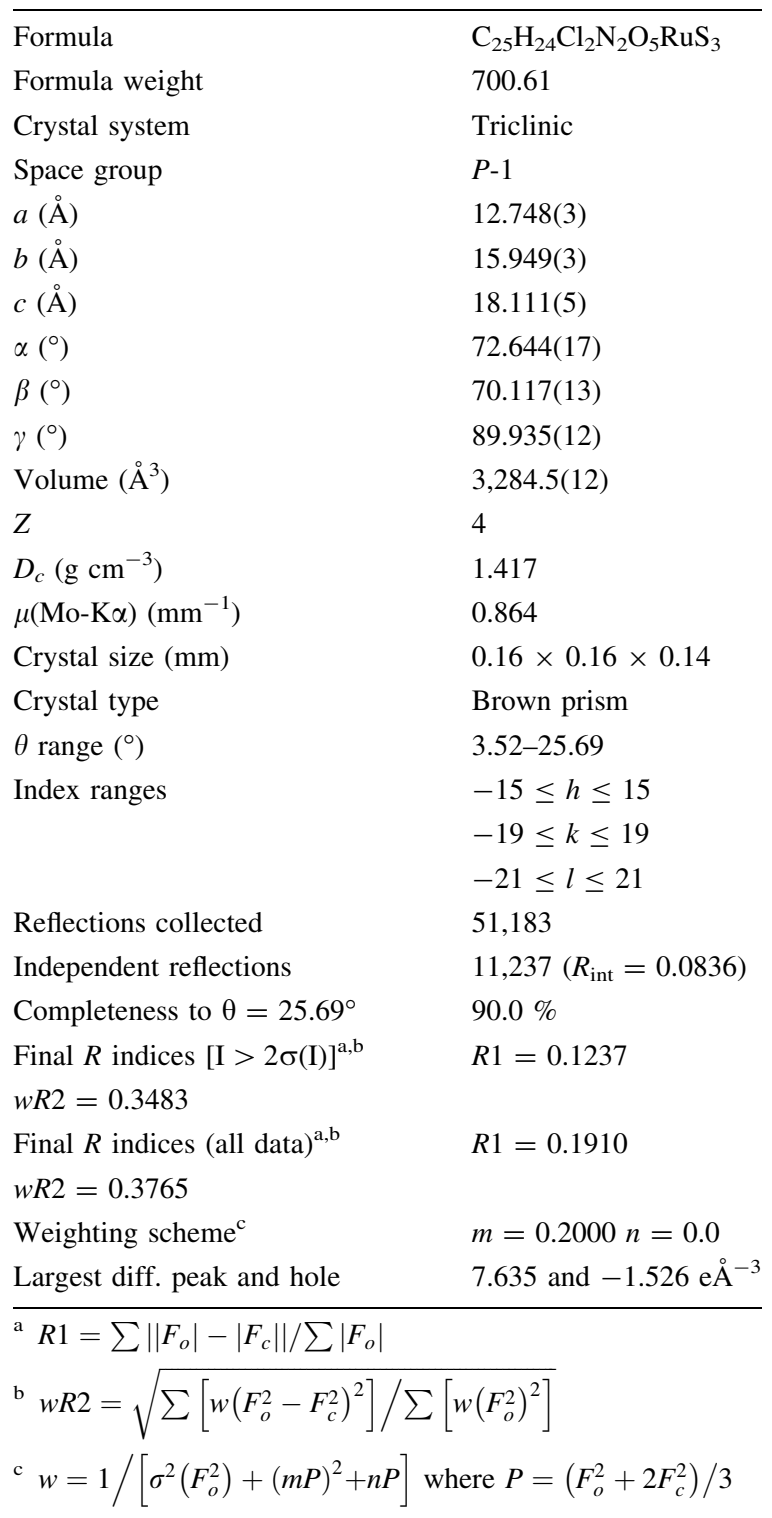

Cambridge CB2 2EZ, U.K. FAX: (+44) 1223336033. E-mail: deposit@ccdc.cam.ac.uk.

CNT preparation and loading tests

\section{Oxidation of the carbon nanotubes}

CNTs oxidation was carried out using acid oxidation, previously shown to optimise sample dispersion and
Table 2 Selected bond lengths (in $\AA$ ) and angles (in ${ }^{\circ}$ ) for the two crystallographically independent $\mathrm{Ru}(\mathrm{II})$ coordination environment present in $\left[\mathrm{Ru}\left([9] \mathrm{aneS}_{3}\right)(\right.$ pdon $\left.) \mathrm{Cl}\right] \mathrm{Cl} \cdot$ (salycilic acid) $x($ solvent $)$

\begin{tabular}{|c|c|c|c|}
\hline Ru1-N1 & $2.117(9)$ & $\mathrm{Ru} 2-\mathrm{N} 3$ & $2.124(10)$ \\
\hline $\mathrm{Ru} 1-\mathrm{N} 2$ & $2.104(5)$ & $\mathrm{Ru} 2-\mathrm{N} 4$ & $2.136(9)$ \\
\hline $\mathrm{Ru} 1-\mathrm{S} 1$ & $2.303(4)$ & $\mathrm{Ru} 2-\mathrm{S} 4$ & $2.301(4)$ \\
\hline Ru1-S2 & $2.296(4)$ & $\mathrm{Ru} 2-\mathrm{S} 5$ & $2.306(4)$ \\
\hline $\mathrm{Ru} 1-\mathrm{S} 3$ & $2.290(3)$ & $\mathrm{Ru} 2-\mathrm{S} 6$ & $2.298(4)$ \\
\hline $\mathrm{Ru} 1-\mathrm{Cl1}$ & $2.431(4)$ & $\mathrm{Ru} 2-\mathrm{Cl} 2$ & $2.430(4)$ \\
\hline N1-Ru1-S1 & $175.1(2)$ & N3-Ru2-N4 & $77.5(4)$ \\
\hline N1-Ru1-S2 & $93.9(2)$ & N3-Ru2-S4 & $94.5(3)$ \\
\hline N1-Ru1-S3 & $96.7(3)$ & N3-Ru2-S5 & $97.5(3)$ \\
\hline N1-Ru1-Cl1 & $87.3(2)$ & N3-Ru2-S6 & 174.3(3) \\
\hline N2-Ru1-N1 & $79.4(3)$ & $\mathrm{N} 3-\mathrm{Ru} 2-\mathrm{Cl} 2$ & $88.2(3)$ \\
\hline N2-Ru1-S1 & $96.1(2)$ & N4-Ru2-S4 & $93.8(3)$ \\
\hline N2-Ru1-S2 & $94.6(2)$ & N4-Ru2-S5 & $174.7(3)$ \\
\hline N2-Ru1-S3 & $175.0(2)$ & N4-Ru2-S6 & $97.6(3)$ \\
\hline N2-Ru1-Cl1 & $87.9(2)$ & $\mathrm{N} 4-\mathrm{Ru} 2-\mathrm{Cl} 2$ & $87.6(3)$ \\
\hline S1-Ru1-Cl1 & $90.70(14)$ & S4-Ru2-S5 & $88.35(16)$ \\
\hline S2-Ru1-S1 & $88.26(15)$ & $\mathrm{S} 4-\mathrm{Ru} 2-\mathrm{Cl} 2$ & $177.16(14)$ \\
\hline S2-Ru1-C11 & $177.33(13)$ & $\mathrm{S} 5-\mathrm{Ru} 2-\mathrm{Cl} 2$ & $90.41(16)$ \\
\hline S3-Ru1-S1 & $87.75(14)$ & S6-Ru2-S4 & $88.73(15)$ \\
\hline S3-Ru1-S2 & $88.64(14)$ & S6-Ru2-S5 & $87.22(15)$ \\
\hline S3-Ru1-Cl1 & $88.86(14)$ & S6-Ru2-Cl2 & $88.66(15)$ \\
\hline
\end{tabular}

afford better aqueous dispersability and biocompatibility (Heister et al. 2010). The experimental procedure and characterisation of the oxidised nanotubes is described in the literature (Heister et al. 2012).

\section{Binding of the Ruthenium compounds to carbon nanotubes}

oxCNTs were mixed with the complex 1 (and also with an analogue complex with a more extended planar aromatic ligand, $\left.\left[\mathrm{Ru}\left([9] \mathrm{aneS}_{3}\right)(\mathrm{dppz}) \mathrm{Cl}\right] \mathrm{Cl}\right)$ at a final CNT concentration of $10 \mu \mathrm{g} / \mathrm{mL}$ and varying the concentrations of the $\mathrm{Ru}$ complex to obtain different Ru-complex/CNT weight ratios, with points at 100:1, 50:1 and 20:1. The samples were buffered at $\mathrm{pH} 7.4$ with sodium phosphate buffer at a final concentration of $5 \mathrm{mM}$. After incubation overnight at room temperature, the samples were filtered using Amicon $^{\circledR} 100 \mathrm{kDa}$ centrifugal filter devices. The unbound complex present in the eluates was quantified by means of UV/vis absorption spectroscopy, with 
working wavelengths of $415 \mathrm{~nm}$ for 1 and of $355 \mathrm{~nm}$ for $\left[\mathrm{Ru}\left([9] \mathrm{aneS}_{3}\right)(\mathrm{dppz}) \mathrm{Cl}\right] \mathrm{Cl}$ (for details on the UV/ vis spectroscopy studies of the complexes, please refer to the Supplementary Information, Sect. S1).

\section{Calf thymus DNA thermal denaturation studies}

The thermal denaturation temperature of $c t$-DNA and of the mixture $1 / c t$-DNA $(1: 10)$ was determined in a $10 \mathrm{mM}$ phosphate buffer $\left(\mathrm{Na}_{2} \mathrm{HPO}_{4} / \mathrm{NaH}_{2} \mathrm{PO}_{4}\right.$, $\mathrm{pH}=7.2$ ) solution prepared with ultra-pure water, containing $1.0 \times 10^{-4} \mathrm{M}$ of $c t$-DNA and $1.0 \times 10^{-5}$ $\mathrm{M}$ of the complex $\mathbf{1}$. Melting curves were recorded on a BioTek microQuant MQX200 UV-Visible spectrophotometer equipped with a NE1B-14 water thermostated bath, heating in steps of $5{ }^{\circ} \mathrm{C}$ with $10 \mathrm{~min}$ interval between each step. For each temperature point, three absorbance readings were collected, at a working wavelength of $260 \mathrm{~nm}$. The three readings for each temperature point were averaged and then fitted to a Boltzmann sigmoid function using GraphPad Prism version 5.00 for Windows, GraphPad Software, San Diego California USA, www.graphpad.com.

Cytotoxic and antiproliferative studies

Compounds 1 to $\mathbf{3}$ were tested on mouse K1735-M2 melanoma, rat $\mathrm{H} 9 \mathrm{c} 2$ myoblasts, and human breast cancer MDA-MB-231 cells; the growth inhibition effect was measured using the SRB colourimetric assay (Skehan et al. 1990; Papazisis et al. 1997). This test is based on the ability of sulforhodamine B, a bright-pink aminoxanthene dye with two sulfonic groups, to stain proteins under mild acidic conditions (binding to basic amino acid residues). The staining is stoichiometric and thus suitable for optical density measurement yielding cell density values. Compounds 1 to 3 , along with the pure cyclodextrins $(\beta-C D$ and TRIMEB), were also tested towards the MCF-7 human breast carcinoma line (estrogen-responsive), their cytotoxicity having been assessed by the mitochondrial dehydrogenase activity assay or MTT colourimetric assay (Mosmann 1983), which is based on the ability of this tetrazolium dye to form an insoluble coloured compound when it is reduced by the intracellular mitochondrial dehydrogenases. Experimental details for the assays are given in the subsections below.

\section{Preparation of the solutions}

All of the compounds studied were water-soluble. The tests on the K1735-M2, H9c2 and MDA-MB-231 cell lines were performed using solutions of 1-3 with concentrations ranging from $1.0 \times 10^{-6}$ to $1.0 \times$ $10^{-4} \mathrm{M}$. For the assays on the MCF-7 cell line, solutions of 1-3 and free CDs were prepared at concentrations ranging from $5.0 \times 10^{-5}$ to $5.0 \times$ $10^{-4} \mathrm{M}$ in phosphate buffered saline (PBS) $(140.0 \times$ $10^{-3} \mathrm{M} \mathrm{NaCl}, 2.7 \times 10^{-3} \mathrm{M} \mathrm{KCl}, 1.5 \times 10^{-3} \mathrm{M}$ $\mathrm{KH}_{2} \mathrm{PO}_{4}, 8.1 \times 10^{-3} \mathrm{M} \mathrm{Na}_{2} \mathrm{HPO}_{4}$ in Milli-Q water, $\mathrm{pH}$ 7.4) and were sterilised by filtration.

MTT was prepared in a concentration of $5 \mathrm{mg} / \mathrm{mL}$ in PBS and the solution was sterilised by filtration.

\section{Cell culture}

K1735-M2 mouse melanoma cells were a kind gift from Dr. Lillian Repesh and Dr. Jon Holy, Department of Biomedical Sciences, University of Minnesota School of Medicine, Duluth, MN, USA. Rat H9c2 cardiomyoblasts (H9c2(21), ATCC ${ }^{\circledR}$ CRL-1446 ${ }^{\mathrm{TM}}$ ) were purchased from the American Type Culture Collection (Manassas, VA). The MDA-MB-231 cell line (human Caucasian estrogen-independent breast adenocarcinoma, catalog reference 92020424) was purchased from the European Collection of Cell Cultures (ECACC, Salisbury, UK), while the MCF-7 line (human Caucasian estrogen-dependent breast adenocarcinoma) was kindly made available by the Biochemistry Service of the Faculty of Medicine of the University of Coimbra.

All cells were cultured in DMEM supplemented with $10 \%$ heat-inactivated fetal bovine serum (FBS), sodium bicarbonate $(1.5 \mathrm{~g} / \mathrm{l})$, penicillin/streptomycin (100 units $/ \mathrm{mL}$ penicillin and $100 \mu \mathrm{g} / \mathrm{mL}$ streptomycin) in $75 \mathrm{~cm}^{2}$ tissue culture flasks at $37^{\circ} \mathrm{C}$ in a humidified atmosphere with $5 \% \mathrm{CO}_{2}$. All cell lines used were grown in monolayers, sub-cultured every 2-3 days and harvested upon addition of trypsin/ EDTA (0.05\% trypsin/EDTA solution).

\section{Growth inhibition assays}

Cell density following exposure of the K1735-M2, H9c2 and MDA-MB-231 cells to $\mathbf{1}, \mathbf{2}$ and $\mathbf{3}$ at 1, 10, 25, 50 and $100 \mu \mathrm{M}$ was assessed, through the SRB test, for 24,48 and $72 \mathrm{~h}$ incubation times. After treatment with the test compound, the incubation medium was removed, the 
microplates were washed with PBS and the cells were fixed in $1 \%$ acetic acid in ice-cold methanol during $2 \mathrm{~h}$. Then, the acetic acid was discarded and the microplates were air-dried. The cells were then incubated with $0.5 \%$ (wt/vol) SRB in $1 \%$ acetic acid for $1 \mathrm{~h}$ at $37{ }^{\circ} \mathrm{C}$. The unbound dye was removed by washing the microplates with a $1 \%$ acetic acid solution. The dye bound to the cell's basic amino acids was extracted with a $10 \mathrm{mM}$ Trizma-base solution, $\mathrm{pH}=10$, and the optical density was measured at $540 \mathrm{~nm}$.

Cell viability following exposure of the MCF-7 cells to 1, 2, 3 and the CDs at 50,100, 200, 300 and $500 \mu \mathrm{M}$ was assessed for a single time point (48 h of incubation) by the MTT assay. Three independent experiments were performed, with triplicates for each concentration of the test compound. The MCF-7 cells were plated at a density of $5.0 \times 10^{4}$ cells $/ \mathrm{mL}$ in 96-well microplates. Twenty-four hours after seeding, test solutions of $\mathbf{1}, \mathbf{2}, \mathbf{3}$ and the CDs were added to the medium and the cultures were incubated at $37{ }^{\circ} \mathrm{C}$. After an incubation period of $48 \mathrm{~h}, 25 \mu \mathrm{L}$ of MTT were added to each well and the microplates were left at $37^{\circ} \mathrm{C}$ for $4 \mathrm{~h}$, after which the MTT was removed by aspiration, and the purple formazan crystals formed in the cells were dissolved by addition of $200 \mu \mathrm{L}$ of dmso under stirring. The optical density was measured in a microplate reader, at a working wavelength of $550 \mathrm{~nm}$.

\section{Statistical analysis}

Growth inhibition data for the K1735-M2, H9c2, MDA-MB-231 and MCF-7 cells resulted from 3 to 4 different cell preparations. The results are expressed as a percentage of the control (100\%) for each time point and represent the mean values \pm standard deviation (the corresponding error bars are displayed in the graphical plots). Statistical analysis was performed by ANOVA (analysis of variance). The Dunnett's post-hoc test was used for statistical comparison between the experimental data, points with $p$-value $<0.05$ having been considered as significant.

\section{Results and discussion}

The guest

The complex $\left[\mathrm{Ru}\left([9] \mathrm{aneS}_{3}\right)(\right.$ pdon$\left.) \mathrm{Cl}\right] \mathrm{Cl}(\mathbf{1})$ is part of a class of trithiacyclononane $\mathrm{Ru}(\mathrm{II})$ complexes with planar amines, which are typically obtained in good yield by refluxing the precursor $\mathrm{Ru}[9] \mathrm{aneS} \mathrm{S}_{3}(\mathrm{dmso}) \mathrm{Cl}_{2}$ with the desired ligand and then cooling the solution to obtain a precipitate. Many of the complexes of this family form microcrystalline precipitates and thus their crystal structures were easily obtained and described over a decade ago (Goodfellow et al. 1997; Madureira et al. 2000; Santos et al. 2001). Compound 1, however, forms a precipitate with low crystallinity and, to date, its detailed structural description, of valuable practical use for assessing possible interaction geometries with both the $\mathrm{CD}$ and the CNT carriers, remains unavailable. We have, thus, carried crystallisation studies of this complex aiming at obtaining suitable crystals for structural determination. Several solvents, and mixtures of solvents, were tested for the crystallisation of 1: ethanol, methanol, water and mixtures of these. The crystallisation attempts were conducted both at room temperature and at low temperatures, first starting at $277 \mathrm{~K}$. No crystals were formed at this temperature so the batch was further cooled to $269 \mathrm{~K}$. At this temperature, some crystals were isolated from the ethanolic solution, but they revealed to be unstable under the X-ray beam thus preventing the complete collection of diffraction data. The difficulties found in crystallising this complex have led us to resource to crystal engineering techniques that use co-crystallisation as a way to obtain stable solid-state systems for molecules otherwise less manageable. Although the concept of co-crystal cannot be textually applied to the complex 1 due to its cationic nature (co-crystals are, by definition, composed of synlets of two neutral units), the presence of a suitable secondary compound was tested as a way to stabilise the intermolecular arrangement of the Ru(II) complexes. Medium-to-low quality crystals, able to be studied using single-crystal $\mathrm{X}$-ray diffraction, were obtained using salycilic acid as adjuvant: besides being capable of both hydrogen donation and acceptance in hydrogen bonding interactions, this molecule also can engage in $\pi-\pi$ interactions in molecular crystals being, thus, suitable to interact with the $N, N$-chelated pdon moiety in $\mathbf{1}$. The isolated crystalline material obtained from the cocrystallisation with salycilic acid could only be solved in the triclinic centrosymmetric $P-1$ space group, with the asymmetric unit being composed of two whole cationic complexes of $\left[\mathrm{Ru}\left([9] \mathrm{aneS}_{3}\right) \text { (pdon)Cl }\right]^{+}$, two salycilic acid moieties plus two charge-balancing 


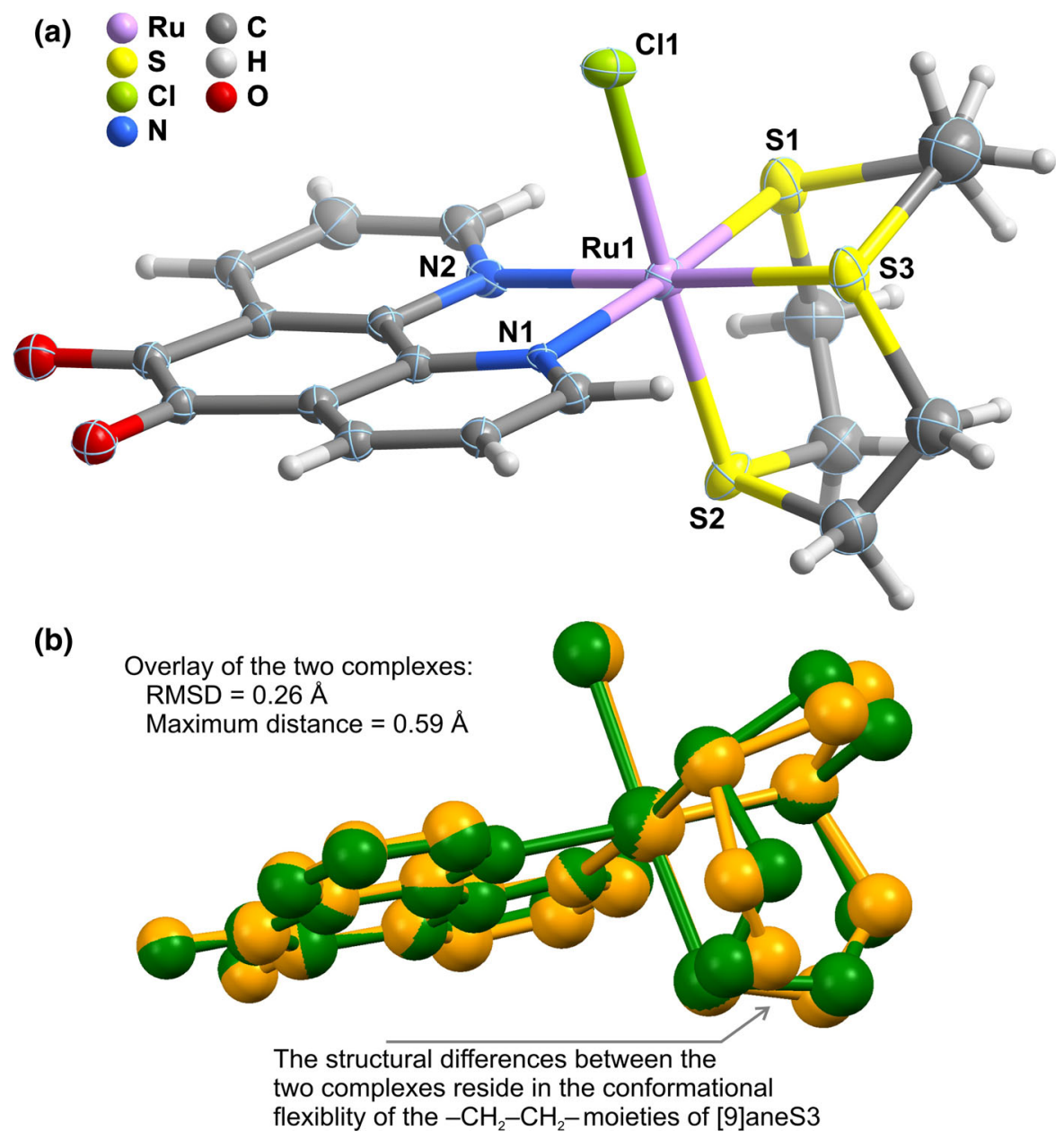

Fig. 1 a Schematic representation of one cationic $[\mathrm{Ru}([9] \mathrm{a}-$ $\mathrm{neS}_{3}$ )(pdon)Cl] ${ }^{+}$complex present in the crystal structure of $\left[\mathrm{Ru}\left([9] \mathrm{aneS}_{3}\right)(\right.$ pdon$\left.) \mathrm{Cl}\right] \mathrm{Cl} \cdot($ salycilic acid) $x$ (solvent). Nonhydrogen atoms are drawn as thermal ellipsoids (at the $50 \%$ probability level) and hydrogen atoms as small spheres with arbitrary radii. The atomic labelling for the first coordination

chloride anions structurally disorder over five distinct crystallographic positions. As detailed in the Experimental Section dedicated to these studies, the poor quality of the diffraction prevented a sensible location and refinement of the solvent molecules which cocrystallise in the interstitial spaces between the aforementioned moieties. The two crystallographically independent cationic $\left[\mathrm{Ru}\left([9] \mathrm{aneS}_{3}\right)(\text { pdon }) \mathrm{Cl}\right]^{+}$ complexes (Fig. 1a) have the same structural arrangement around the $\mathrm{Ru}$ (II) metallic centre, with the main differences residing solely on the chelating [9] $\mathrm{aneS}_{3}$ moieties which exhibit slightly distinct conformations sphere of Ru1 is provided. For selected bond lengths (in $\AA$ ) and angles (in ${ }^{\circ}$ ) see Table 2, which also contains the analogous values for the other crystallographically independent complex composing the asymmetric unit. b Overlay of the two cationic $\left[\mathrm{Ru}\left([9] \mathrm{aneS}_{3}\right)(\text { pdon}) \mathrm{Cl}\right]^{+}$complexes composing the asymmetric unit of $\left[\mathrm{Ru}\left([9] \mathrm{aneS}_{3}\right)(\right.$ pdon $\left.) \mathrm{Cl}\right] \mathrm{Cl} \cdot($ salycilic acid $) \cdot x$ (solvent)

for the $-\mathrm{CH}_{2}-\mathrm{CH}_{2}-$ : as depicted in Fig. 1b, the overlap between the two complexes is almost perfect for most of the atoms with the sole differences being in these carbon atoms. The two Ru(II) metallic centres exhibit almost identical slightly distorted octahedral coordination environment, $\left\{\mathrm{RuClN}_{2} \mathrm{~S}_{3}\right\}$ : while the equatorial plane being composed of the $N, N$-chelated pdon moiety and two sulfur atoms, the apical positions are instead occupied by the coordinated chlorido anion and the additional sulfur atom from [9]aneS ${ }_{3}$ (Fig. 1a). We note that the octahedral distortion of the complexes is mainly attributed to the various types of the 
coordinating atoms (arising from three distinct coordinating ligands), which impose a wide range of bond lengths: the $\mathrm{Ru}-\mathrm{N}$ bonds to the $N, N$-chelated pdon moieties are the shortest ranging from 2.104(5) to 2.136(9) $\AA$, which contrast with the $\mathrm{Ru}-\mathrm{Cl}$ bonds which are almost identical for the two complexes (Table 2); the $\mathrm{Ru}-\mathrm{S}$ bonds to the [9] $\mathrm{aneS}_{3}$ moieties were found in the 2.290(3)-2.306(4) $\AA$ range. On the other hand, the cis and trans octahedral angles are significantly more regular, being found in the 77.5(4)$97.6(3)^{\circ}$ and $174.3(3)-177.33(13)^{\circ}$ ranges, respectively (Table 2; please note: the shortest cis angle corresponds, as expected, to the bite angle of a $N, N$ chelated pdon ligand).

\section{Interaction with CNTs}

The present work used oxidised CoMoCAT CNTs (oxCNTs) with a high aqueous dispersibility, which are good candidates for the development of a CNTbased drug delivery system. The complex 1 was incubated for $24 \mathrm{~h}$ with these oxCNTs at different drug/CNT weight ratios. The binding rate for the incubated mixtures with a drug/CNT weight ratio of 100:1, 50:1 and 20:1 was monitored by UV/Vis spectroscopy (details in the Experimental Section) and exhibited very low values: less than $5 \%$ of the complex 1 was loaded onto the CNTs (Fig. 2). Given that drug-CNT interactions are typically of the $\pi-\pi$ type, these results can be perceived as evidence that the conjugated $\pi$-electron system of the pdon fragment is insufficient for proper anchoring onto the

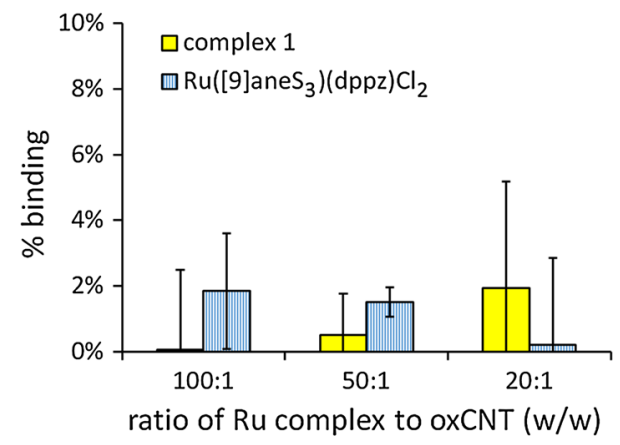

Fig. 2 Loading rate (in \%) of two ruthenium complexes, 1 and its analogue $\left[\mathrm{Ru}\left([9] \mathrm{aneS}_{3}\right)(\mathrm{dppz}) \mathrm{Cl}\right] \mathrm{Cl}$, onto oxCNTs in function of the complex/oxCNT weight ratios $(n=3)$. Only the ratios which translate into concentrations of oxCNT useful for therapeutics are shown
CNT carriers. Further tests were conducted using the same experimental conditions on another $\mathrm{Ru}(\mathrm{II})$ complex bearing, in the place of pdon, a more extended conjugated ligand, dppz (dipyrido[3,2$\mathrm{a}: 2^{\prime}, 3^{\prime}$-c]phenazine). Still, the binding rate for this complex has increased only very slightly, with a loading rate below $10 \%$. These results indicate that CNTs cannot be used as carriers for this family of ruthenium(II) complexes.

It should also be noted that further increasing the amount of available CNT in relation to the drug did increase the loading rate (details in the Supplementary Information, Sect. S2), but our experiments conducted in this regard show that a very high ratio of CNT is required to achieve loadings of $100 \%$ of the complex 1. The end result is a final product containing a high concentration of CNT, which could generate carrierderived cytotoxicity.

Molecular encapsulation of $\mathbf{1}$ with cyclodextrins

Inclusion of the complex 1 into the two CD hosts was carried out starting from an initial $\mathrm{CD}$ /guest molar ratio of $1: 1$ and followed a strategy based on the relative solubilities of the $\mathrm{CDs}$, using ethanol/acetone as solvent for TRIMEB (Petrovski et al. 2005a, b). For $\beta-C D$, which is insoluble in organic solvents, we took advantage of the fair aqueous solubility of the guest $\mathbf{1}$ and used water as the solvent. To minimise hydrolysis, we resourced to a methodology we had previously developed for easily hydrolysable guest molecules (Braga et al. 2001), which consists of a very short costirring time (10 min) with subsequent snap-freezing and freeze-drying for water removal. Elemental analysis data (details in the Experimental Section) is coherent with a 1:1 host-to-guest stoichiometry in both 2 and 3.

The initial assessment of the inclusion of the complex 1 into $\beta C D$ and TRIMEB is based on FT-IR spectroscopy studies. It is common to observe some shifts in the guest bands upon the formation of inclusion compounds. In $\beta-\mathrm{CD} \cdot\left[\mathrm{Ru}\left([9] \mathrm{aneS}_{3}\right)(\right.$ pdon) $\mathrm{Cl}] \mathrm{Cl}(\mathbf{2})$, shifts were observed in the major functional groups. The bands ascribed to $v(\mathrm{C}=\mathrm{O})$ and $\delta(\mathrm{C}-[\mathrm{C}=\mathrm{O}]-\mathrm{C})$, found at 1691 and $1295 \mathrm{~cm}^{-1}$ for the complex $\mathbf{1}$, are blueshifted upon inclusion to 1698 and $1299 \mathrm{~cm}^{-1}$, respectively, in 2 (Nakamoto 1966). The $\delta(\mathrm{C}-\mathrm{H})$ band for the [9] $\mathrm{aneS}_{3}$ fragment also shifts from $1418 \mathrm{~cm}^{-1}$ in 1 to $1423 \mathrm{~cm}^{-1}$ in the adduct 2 . In turn, in the spectrum of 
the compound TRIMEB·[Ru([9]aneS $\left.\left.{ }_{3}\right)(\operatorname{pdon}) \mathrm{Cl}\right] \mathrm{Cl}(\mathbf{3})$, the bands associated with the functional groups of the guest appear unshifted. The results are an initial indication that $\beta-\mathrm{CD} \cdot\left[\mathrm{Ru}\left([9] \mathrm{aneS}_{3}\right)(\mathrm{pdon}) \mathrm{Cl}\right] \mathrm{Cl}(\mathbf{2})$ is a true inclusion compound whereas in $\mathbf{3}$ there seems to occur no true inclusion (which is confirmed by powder diffraction data, as detailed below).

\section{Powder X-ray diffraction studies of $\mathbf{2}$ and $\mathbf{3}$}

X-ray powder diffraction studies allow the identification of true inclusion compounds of cyclodextrins, mainly based on the fact that these crystallise in wellknown sets of distinct three-dimensional arrangements, or "isostructural series" (Caira 2001). Figure 3 shows the patterns for the complex $\mathbf{1}$, the hosts $\beta-\mathrm{CD}$ and TRIMEB, and their corresponding adducts $\mathbf{2}$ and 3. The powder diffractogram for the adduct $\mathbf{2}$ presents low crystallinity, with absence of reflections associated with the uncomplexed guest $\mathbf{1}$ and an overall envelope which matches the isostructural series 7 described by Caira (2001). This means that the most dominant phase in the adduct corresponds to an arrangement of the $\beta-C D$ molecules in a cage packing mode, common in $\beta$-CD inclusion complexes of small organic guests and not much different from that found for $\beta$-CD hydrate. The existence of this type of crystal packing in compound $\mathbf{2}$ is seemingly surprising given that the guest complex $\mathbf{1}$ is somewhat bulky, yet it has been previously observed by us for the compound $\beta$ $\mathrm{CD} \cdot\left[\mathrm{CpMo}(\mathrm{CO})_{3} \mathrm{Cl}\right]$ (Braga et al. 2006) and also for the $\beta$-CD inclusion compound with a ruthenium guest of the same family, $\left[\mathrm{Ru}\left([9] \mathrm{aneS}_{3}\right)(\right.$ phen) $\mathrm{Cl}] \mathrm{Cl}$ (Marques et al. 2009a). Furthermore, the structural resemblance of the latest guest to that of the complex $\mathbf{1}$ allows us to infer that their $\beta$-CD inclusion compounds feature similar packing (see the schematics on the right side of the Fig. 3).

The XRD pattern for TRIMEB.[Ru[9]ane $S_{3}$ (pdon) $\mathrm{Cl}] \mathrm{Cl}$ (3) is clearly dominated by reflections corresponding to the guest whilst TRIMEB is present as an amorphous phase. It can be described as a dispersion of the guest in the TRIMEB phase with a consequent disruption of the host packing thus rendering it vitreous. Indeed, in practical terms, there is not a true host-guest inclusion in $\mathbf{3}$; this also explains the unshifted vibrational bands of the complex $\mathbf{1}$ observed in the FT-IR spectrum of $\mathbf{3}$ (as mentioned in the previous subsection).

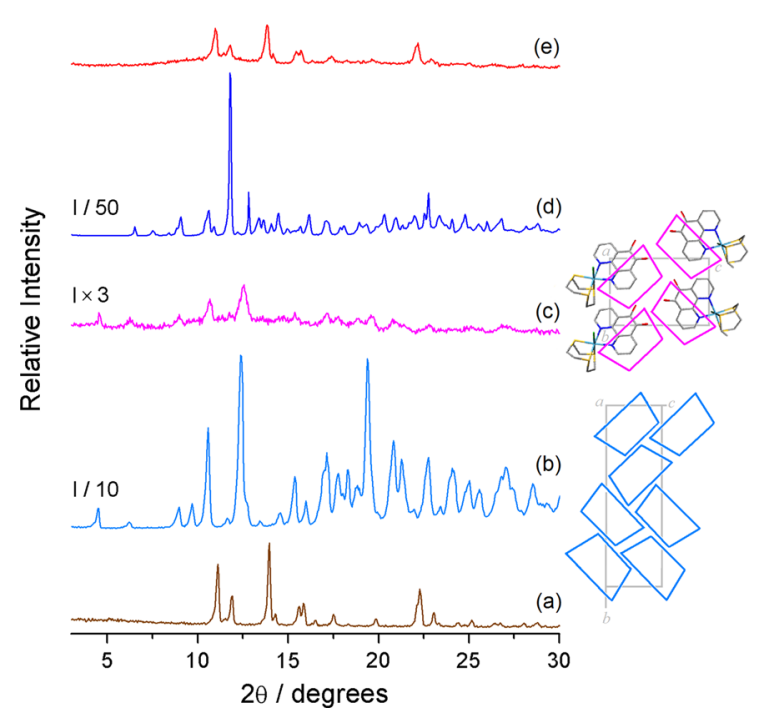

Fig. 3 Laboratory powder diffraction data for compound $\left[\mathrm{Ru}\left([9] \mathrm{aneS}_{3}\right)(\right.$ pdon$\left.) \mathrm{Cl}\right] \mathrm{Cl}$ (1) (a), $\beta-\mathrm{CD}(\mathbf{b})$, adduct 2 (c), TRIMEB (d) and adduct $\mathbf{3}$ (e), and schematic representation of $\beta-\mathrm{CD}$ packing for the pure hydrate and for adduct $\mathbf{2}$

\section{Thermogravimetric analysis}

Thermogravimetric analysis is another useful tool in the investigation of the formation of inclusion compounds. The traces of the compounds $\mathbf{1}, \mathbf{2}$ and $\mathbf{3}$ and of the physical mixtures (mix) of $\mathbf{1}$ with the two cyclodextrin hosts are represented in the Fig. 4. The adduct $\beta-\mathrm{CD} \cdot\left[\mathrm{Ru}\left([9] \mathrm{aneS}_{3}\right)(\mathrm{pdon}) \mathrm{Cl}\right] \mathrm{Cl}$ (2) features an overall thermal decomposition similar to that of the corresponding 1:1 (host:guest) physical mixture, with the only difference found for the onset of $\beta-C D$ decomposition. In fact, 2 starts to decompose around $240{ }^{\circ} \mathrm{C}$, a temperature lower than that found for the mix $\left(250^{\circ} \mathrm{C}\right)$ and even lower that the one of plain $\beta-\mathrm{CD}$ hydrate $\left(270{ }^{\circ} \mathrm{C}\right.$, trace not shown). Such a difference is attributed to the promoting effects of the ruthenium guest on the decomposition of $\beta$-cyclodextrin, and it is an evidence of the existence of a significant host-guest interaction in 2 (Harada et al. 1989).

An opposite effect is observed with the adduct TRIMEB $\cdot\left[\mathrm{Ru}\left([9] \mathrm{aneS}_{3}\right)\right.$ (pdon)Cl]Cl (3). While pure TRIMEB starts to melt and decompose at about $175^{\circ} \mathrm{C}$ (not shown), the adduct 3 features only a very smooth mass loss starting at $180{ }^{\circ} \mathrm{C}$ until around $260{ }^{\circ} \mathrm{C}$, which marks the onset of an abrupt mass loss. The overall thermal decomposition trace of $\mathbf{3}$ is identical to that of the physical mixture, thus showing that the host-guest interaction is of the same nature as 


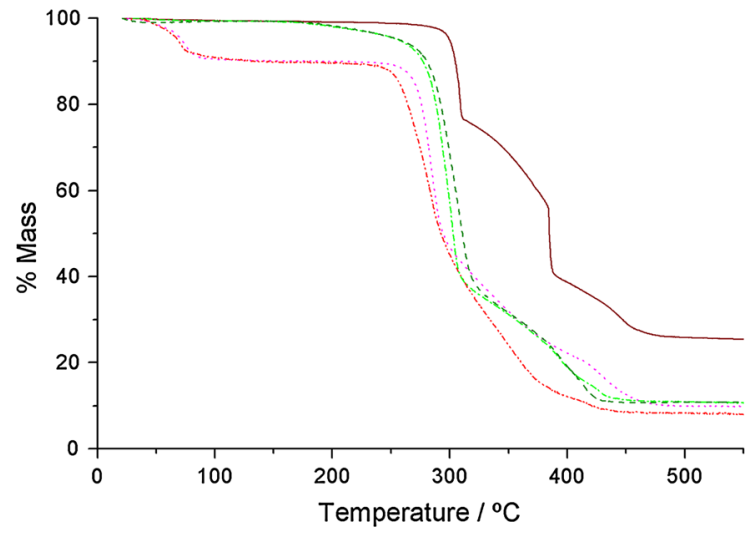

Fig. 4 TG traces for the complex $\left[\mathrm{Ru}\left([9] \mathrm{ane} \mathrm{S}_{3}\right)(\right.$ pdon $\left.) \mathrm{Cl}\right] \mathrm{Cl}$ (1) $(-)$, the adduct $\beta-\mathrm{CD} \cdot\left[\mathrm{Ru}\left([9] \mathrm{aneS}_{3}\right)(\right.$ pdon $\left.) \mathrm{Cl}\right] \mathrm{Cl}(-\cdot \cdot-\cdot \cdot)$, the $1: 1$ physical mixture of $\beta-C D$ and $\mathbf{1}(\cdots)$, the adduct TRIMEB $\left[\mathrm{Ru}\left([9] \mathrm{aneS}_{3}\right)(\right.$ pdon$\left.) \mathrm{Cl}\right] \mathrm{Cl}\left(-{ }_{-}\right)$, and the $1: 1$ physical mixture of TRIMEB and $\mathbf{1}(-\cdot-\cdot-)$

one that is obtained by a few seconds of mechanical grinding (for details on the preparation of the mixtures, please refer to the Experimental Section). It is worth noting that this interaction, although not of the inclusion kind (according to powder diffraction results), results in an increased thermal stability of the host, as evidenced by the absence of the expected well-defined step around $175{ }^{\circ} \mathrm{C}$ corresponding to the onset of TRIMEB decomposition. The increase in the host decomposition temperature has been previously observed for TRIMEB inclusion compounds of other $\mathrm{Ru}[9] \mathrm{aneS}_{3}$ complexes (Marques et al. 2008) and also with metallocene guests of formula $\mathrm{Cp}_{2} \mathrm{MCl}_{2}$ where $\mathrm{M}=\mathrm{Mo}, \mathrm{Nb}$ and $\mathrm{Cp}=$ cyclopentadienyl (Braga et al. 2006, Pereira et al. 2007).

\section{${ }^{13} C\left\{{ }^{1} H\right\} C P / M A S N M R$}

The spectra of $\mathbf{1}$ and the compounds $\mathbf{2}$ and $\mathbf{3}$, depicted in Fig. 5, are described in comparison with those of the pure hosts (not shown). $\beta-\mathrm{CD}$ hydrate typically exhibits a spectrum with multiple sharp resonances for each carbon atom associated with small variations in local geometrical parameters; in the spectrum of $\beta-\mathrm{CD} \cdot\left[\mathrm{Ru}\left([9] \mathrm{aneS}_{3}\right)(\right.$ pdon$\left.) \mathrm{Cl}\right] \mathrm{Cl}$ (2) these carbons appear mainly as single broad peaks, with little or no structure, centred around 81, 73, and $61 \mathrm{ppm}$ for the $\mathrm{C}_{4}$, the $\mathrm{C}_{2,3,5}$, and the $\mathrm{C}_{6}$ carbons, respectively. The resonances for the $C_{1}$ carbons of $\beta-C D$ are represented by a set of two poorly resolved broad peaks around

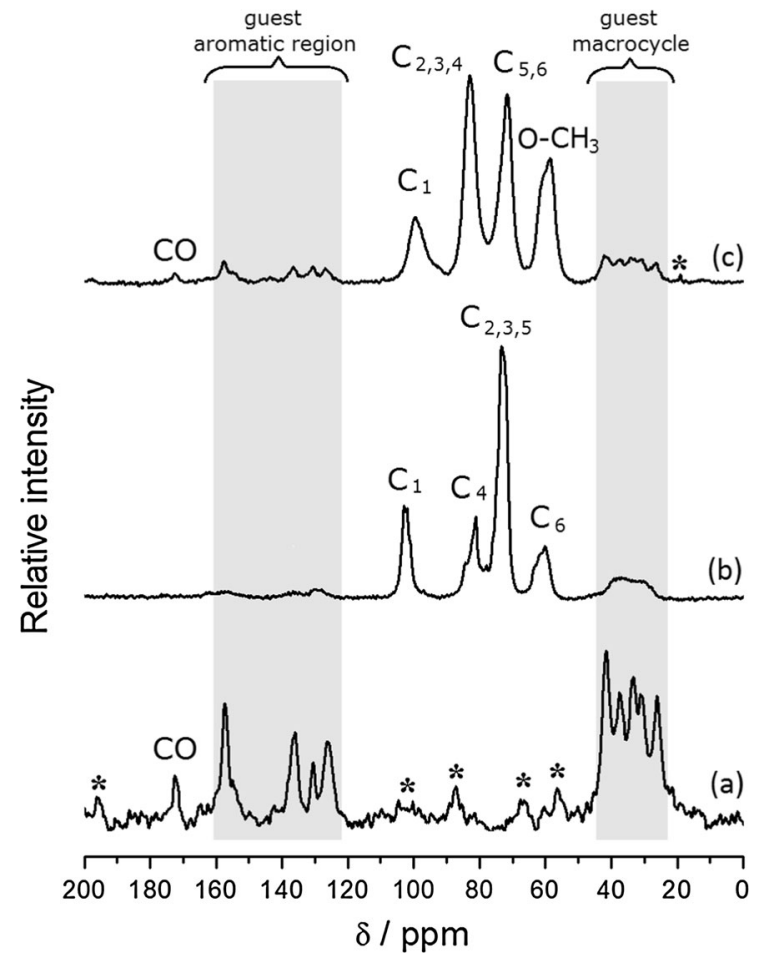

Fig. $5{ }^{13} \mathrm{C}\left\{{ }^{1} \mathrm{H}\right\} \mathrm{CP} / \mathrm{MAS}$ spectra for: a the complex $\mathbf{1}$, b the $\beta$-CD adduct $\mathbf{2}$ and $\mathbf{c}$ the TRIMEB adduct $\mathbf{3}$. Spinning sidebands are denoted by asterisks

102.9 and $101.9 \mathrm{ppm}$. These observations are consonant with loss of crystallinity of the host, as evidenced by powder diffraction, but they have also been associated with partial symmetrisation of the $\beta-C D$ ring. In fact, the encapsulation of a guest molecule usually induces the ring to adopt a less distorted conformation, with each glucose unit in a more similar environment (Braga et al. 2001; Fernandes et al. 2005; Braga et al. 2006; Pereira et al. 2007). The guest resonances appear poorly resolved. A broad set of signals in the 40-26 ppm is ascribed to the resonances of the trithiacyclononane macrocycle. Note that this is a smaller dispersion range when compared with pure $\mathbf{1}$, for which the [9] $\mathrm{aneS}_{3}$ carbon resonances are found in the 44-24 ppm interval (grey-highlighted area on the right side of Fig. 5). We may thus infer that, as a result of a more uniform environment provided by the cavity of $\beta-\mathrm{CD}$, the trithiacyclononane macrocycle, disordered in the pure complex 1 (as described in the previous paragraphs for the crystal structure of the cocrystal of 1 with salicylic acid), becomes less disordered, which translates into a smaller dispersion of its 
carbon resonances observed by CP/MAS NMR spectroscopy. The aromatic carbon resonances in $\mathbf{2}$ appear as weak broad signals peaking at 129, 136, 156 and $161 \mathrm{ppm}$ (slightly shifted in comparison to those of the complex 1, see grey-highlighted area on the left of Fig. 5). It was not possible to clearly identify the resonances (masked in the background) for the guest CO groups in the adduct 2 .

Like plain $\beta$-CD hydrate, the ${ }^{13} \mathrm{C}\left\{{ }^{1} \mathrm{H}\right\} \mathrm{CP} / \mathrm{MAS}$ NMR spectrum of the TRIMEB host (not shown) also shows multiple resonances for each type of carbon atom, caused by a collapsed shape for the macrocycle, with one glucose in the ring inverted to the ${ }^{1} \mathrm{C}_{4}$ conformation in monohydrated TRIMEB molecules, and by an overall asymmetry in the local environment of the glucose units due to self inclusion of two primary methoxyl groups from a neighbouring molecule in the anhydrous TRIMEB molecules (Caira et al. 2004). The multiplicity is lost in the adduct $\mathbf{3}$ and only broad peaks are observed, most likely due to loss of crystallinity of this host, as shown by powder diffraction studies. The resonances ascribed to the guest have suffered no significant chemical shifts, as would be expected due to lack of inclusion interactions in 3, and are somewhat less resolved, which is consistent with the reduction of crystalline material corresponding to the guest, also observed in the powder XRD trace of $\mathbf{3}$.

Biological activity of the complex $\mathbf{1}$ and the adducts $\mathbf{2}$ and $\mathbf{3}$

\section{Thermal denaturation of $c t-D N A$}

This study provides evidence for the intercalation of small molecules into the DNA double helix, measurable from the increase of the DNA melting temperature $\left(T_{m}\right)$, i.e., the temperature at which double stranded DNA denatures into single stranded DNA. The melting curve of $c t$-DNA in the absence and presence of different concentrations of the Ru(II) complex 1 are presented in Fig. 6. Under our experimental conditions, the $T_{m}$ value of $c t$-DNA was found to be $76.53{ }^{\circ} \mathrm{C}$ in the absence of $\mathbf{1}$ and, in the presence of the complex $\mathbf{1}$, at a ratio of $[c t$-DNA $] /[1]=10: 1$, the melting temperature was enhanced. The $\Delta T_{m}$ value of $2.3{ }^{\circ} \mathrm{C}$ is indicative of an intercalative agent $\left(\Delta T_{m}>2{ }^{\circ} \mathrm{C}\right)$. The complex 1 has a low intercalative affinity, below that of its dppz-bearing analogue, $\left[\operatorname{Ru}\left([9] \operatorname{aneS}_{3}\right)(\mathrm{aa})(\mathrm{dppz})\right]^{+}$,

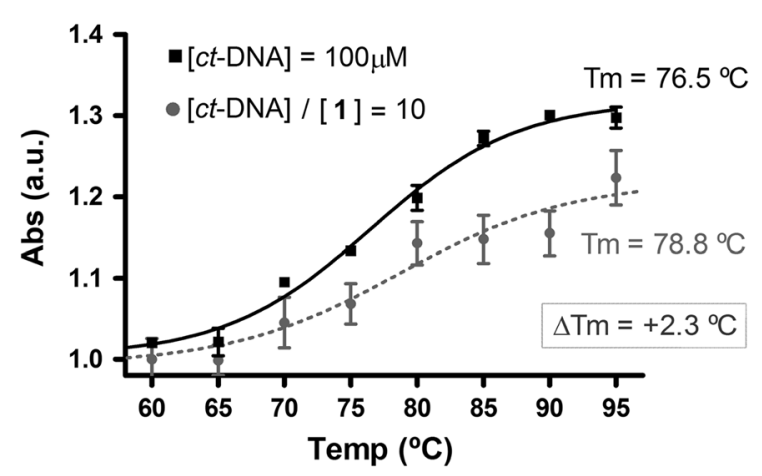

Fig. 6 Comparison of the thermal denaturation curves for $\left(A_{260}\right.$ vs. temperature) for pure $c t$-DNA and the mixture $c t$-DNA/ complex 1 using a 10:1 molar ratio

with a $\Delta T_{m}$ value of $7.0{ }^{\circ} \mathrm{C}$, and also below that of another literature complex, $\left[\left(\eta^{6}-p\right.\right.$-cymene $) \operatorname{Ru}(\mathrm{aa})$ $(\mathrm{dppz})]^{+}$, with a $\Delta T_{m}$ value of $5.7^{\circ} \mathrm{C}$ and where aa $=$ methoxymethionine and $\mathrm{dppz}=\operatorname{dipyrido}[3,2-$ $a: 2^{\prime}, 3^{\prime}-c$ ]phenazine, (Frodl et al. 2002). Most likely, this happens because the length of the pdon ligand is somewhat short to facilitate a deep intercalation between the base pairs of the DNA, whereas the extended planar aromatic amine ligand dppz affords stronger intercalative interactions. The $\Delta T_{m}$ value of the complex 1 matches that of the metallointercalator $\left[\mathrm{Ru}(\mathrm{dmb})_{2}(\mathrm{bdppz})\right]^{+}$(bdppz = dppz-benzomethanone), postulated to present a modest affinity to intercalate with DNA as a result of steric hindrance arising from the dimethylbipyridine (dbm) ligands (Kumar et al. 2009). It can thus be concluded that the $\Delta T_{m}$ value of the complex $\mathbf{1}$ is a combined result of the steric effect of the face-capping ligand, [9] $\mathrm{aneS}_{3}$, with the small area of $\pi-\pi$ interactions arising from the short length of the planar aromatic ligand, pdon.

\section{Cytotoxicity on mouse melanoma and rat cardiomyoblast lines}

The cytotoxic action of compounds 1-3 was first evaluated on cultured mouse melanoma K1735-M2 and rat $\mathrm{H} 9 \mathrm{c} 2$ cardiomyoblasts using the colourimetric assay sulforhodamine B, which measures cell mass, having thus direct correspondence with cell viability. The K1735-M2 melanoma cell line, when incubated with different complex 1 concentrations and at different times (Fig. 7), showed a significant growth inhibition for the higher concentration $(100 \mu \mathrm{M})$, which started at $24 \mathrm{~h}$ and increased until $72 \mathrm{~h}$ of incubation; toxicity was also 
found for $24 \mathrm{~h}$ for $50 \mu \mathrm{M}$. After $96 \mathrm{~h}$ of incubation, no significant alterations in cell proliferation were found for K1735-M2 cells incubated with $\mathbf{1}$, suggesting cell recovery for longer times. $\beta-\mathrm{CD} \cdot\left[\mathrm{Ru}\left([9] \mathrm{aneS}_{3}\right)\right.$ (pdon) $\mathrm{Cl}] \mathrm{Cl}$ (2) was more potent in decreasing cell viability, which may indicate a potentiating effect of $\beta-\mathrm{CD}$ on the antiproliferative activity of $\left[\mathrm{Ru}\left([9] \mathrm{aneS}_{3}\right)(\mathrm{pdon}) \mathrm{Cl}\right] \mathrm{Cl}$. The strongest inhibitory effect was observed for the incubation time of $48 \mathrm{~h}$, with concentrations of $10-50 \mu \mathrm{M}$ decreasing cell viability by $25-40 \%$. For the shortest time point ( $24 \mathrm{~h}$ ), only the concentrations of $50 \mu \mathrm{M}$ and $100 \mu \mathrm{M}$ had a significant effect, while for the $72 \mathrm{~h}$ time point, $50 \mu \mathrm{M}$ of the adduct 2 decreased cell viability (by about $35 \%$ ). We note also that, similarly to the results obtained with the pure complex $\left[\mathrm{Ru}\left([9] \mathrm{aneS}_{3}\right)\right.$ (pdon) $\left.\mathrm{Cl}\right] \mathrm{Cl}(\mathbf{1})$, no inhibition occured at the longest incubation time, which is ascribed to the recovery of the cells for longer treatment times. Cell inhibition properties of TRIMEB $\cdot\left[\operatorname{Ru}\left([9] \mathrm{aneS}_{3}\right.\right.$ )(pdon) $\mathrm{Cl}] \mathrm{Cl}(3)$ are very similar to those of $\mathbf{1}$, which is interpreted as a result of the absence of a true inclusion interactions in 3. A consistent inhibition of cell proliferation at $100 \mu \mathrm{M}$ concentration for all of the incubation times was observed. This included the $96 \mathrm{~h}$ time point, which was not observed for 1 . Also, the inhibitory effect was slightly stronger, which may be associated with the promoting effects of TRIMEB on drug solubility and cell membrane permeability (Ramos et al. 2012).

The H9c2 cell line is a model for muscle tissue, being also a valuable in vitro model to investigate drug-induced cardiac toxicity (Sardão et al. 2009; Branco et al. 2011, 2012). Incubation of the compounds 1-3 with cells from this cell line (Fig. 8) shows that both the complex $\mathbf{1}$ and its $\beta$-CD adduct, $\mathbf{2}$, did not present any toxicity, and only $\mathbf{3}$ decreased cell viability. Indeed, $\mathbf{3}$ presented growth inhibition for $100 \mu \mathrm{M}$ for all time points and $50 \mu \mathrm{M}$ for $72 \mathrm{~h}$. The combination of such results suggests that these compounds are good candidates for anti-cancer therapy, especially $\mathbf{1}$ and $\mathbf{2}$, which are relatively innocuous on the non-tumoural $\mathrm{H} 9 \mathrm{c} 2$ cell line. 3 is also worthy of further studies since it is less toxic against the $\mathrm{H} 9 \mathrm{c} 2$

\section{K-1735-M2 cell line}
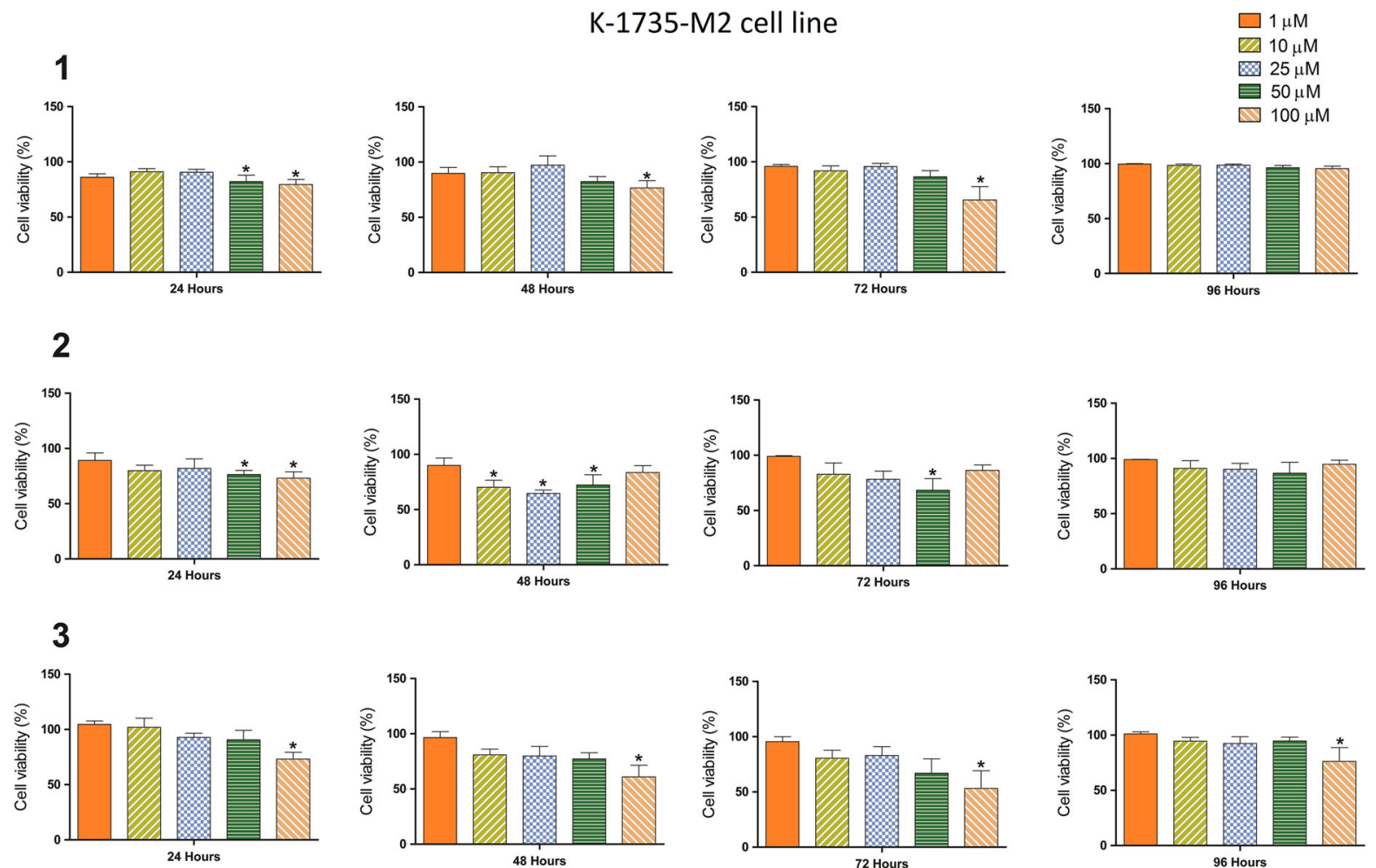

Fig. 7 Antiproliferative effect of the complex 1 and of the adducts $\mathbf{2}$ and $\mathbf{3}$ against K1735-M2 mouse melanoma cells for concentrations ranging from 1 to $100 \mu \mathrm{M}$ and incubation times of 24, 48, 72 and $96 \mathrm{~h}$. Cell number was analysed by using the
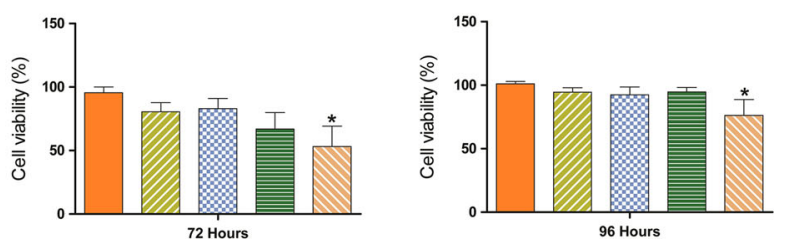

SRB colourimetric assay. Data represent mean \pm SEM of 4 different cell preparations. The asterisk represents statistically significant growth inhibition by Dunnet's post-hoc test after one-way ANOVA $(* p$-value $<0.05)$ 

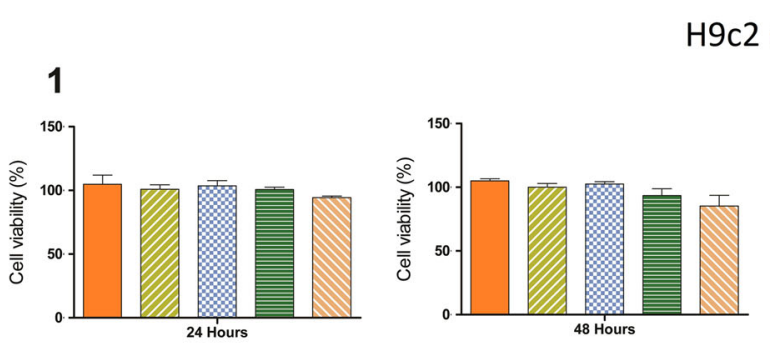

H9c2 cell line
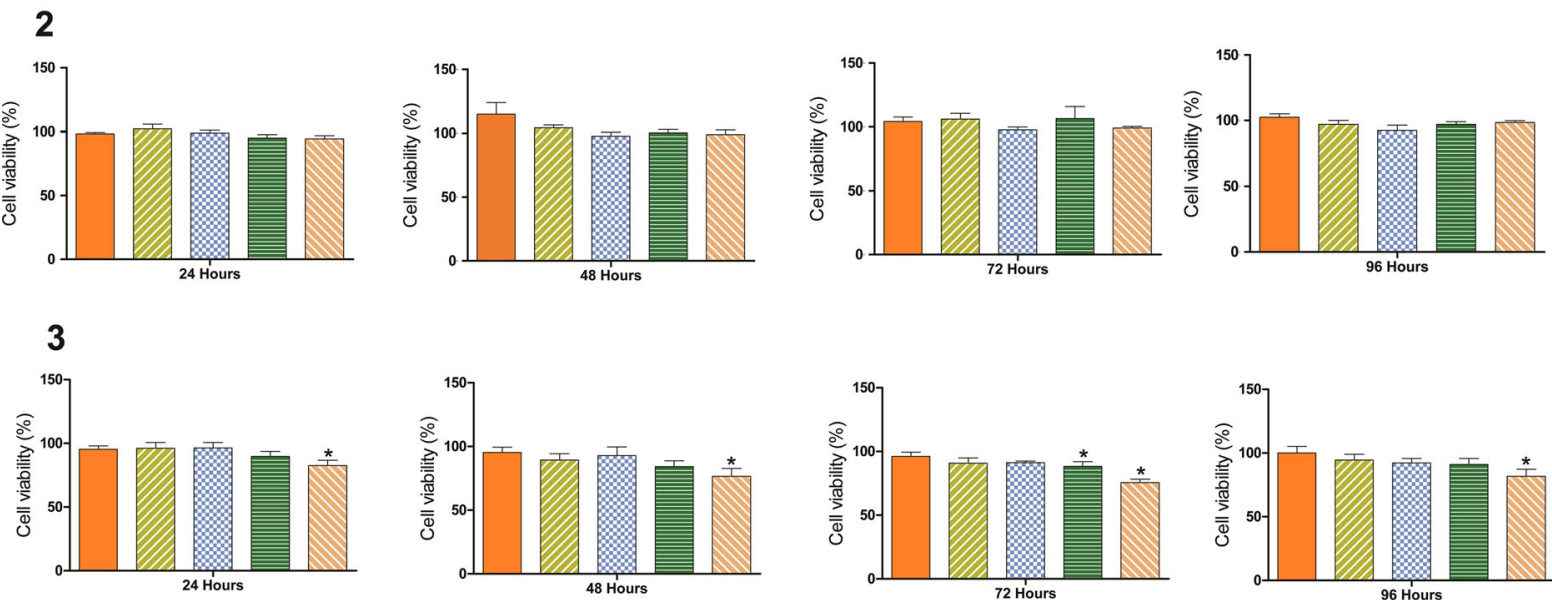

Fig. 8 Antiproliferative effect of the complex $\mathbf{1}$ and of the adducts $\mathbf{2}$ and $\mathbf{3}$ against rat $\mathrm{H} 9 \mathrm{c} 2$ cardiomyoblast cells for concentrations ranging from 1 to $100 \mu \mathrm{M}$ and incubation times of $24,48,72$ and $96 \mathrm{~h}$. Cell number was analysed by using the

line than against the murine K1735-M2 melanoma cell line.

\section{Cytotoxicity on human cancer cell lines}

Following the interesting results gathered for the rodent cell lines, in particular concerning the apparent safety of the compounds $\mathbf{1}-\mathbf{3}$, their cytotoxicity against human breast cancer cell lines, one being estrogen-independent (MDA-MB-231) and another being estrogen-responsive (MCF-7), was investigated in the next step.

Figure 9 shows the results obtained on the estrogen-independent human breast cancer MDA-MB-231 cell line. The results contrast with those obtained with the murine K1735-M2 line, since only complex 1 and its TRIMEB product 3 showed cytotoxicity. Growth inhibition with 1 occurred only for $100 \mu \mathrm{M}$ at the longest incubation time $(96 \mathrm{~h})$, while the murine K1735-M2 cell line was sensitive to 1 at the shorter incubation times and apparently recovering at $96 \mathrm{~h}$.
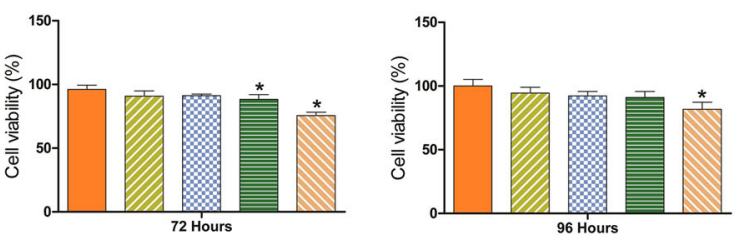

SRB colourimetric assay. Data represent mean \pm SEM of 4 different cell preparations. The asterisk represents statistically significant growth inhibition by Dunnet's post-hoc test after one-way ANOVA (*p-value $<0.05$ )

The TRIMEB product 3 was more potent, inhibiting cell viability for 50 and $100 \mu \mathrm{M}$ for $48 \mathrm{~h}$ besides the inhibition at $100 \mu \mathrm{M}$ for $96 \mathrm{~h}$ of incubation. It is also noteworthy that the percentage of MDA-MB-231 cell growth inhibition after $96 \mathrm{~h}$ of incubation with $100 \mu \mathrm{M}$ of complexes $\mathbf{1}$ and $\mathbf{3}$ is around $48-50 \%$, which allows to estimate an $\mathrm{IC}_{50}$ of $100 \mu \mathrm{M}$ against this particular cell line.

The antiproliferative effects of the compounds 1-3, as well as the cytotoxicity of the pure hosts, $\beta-C D$ and TRIMEB, were further assessed on the estrogendependent MCF-7 human breast cancer cell line (Fig. 10). Given that previous results showed a higher anti-proliferative activity for an incubation time of $48 \mathrm{~h}$ in the previously tested tumour cell lines, this time point was used for collecting further data. In addition, the tested compounds were incubated at higher concentrations $(200,300$ and $500 \mu \mathrm{M})$, to allow the calculation of the corresponding $\mathrm{IC}_{50}$ value for the MCF-7 line. 

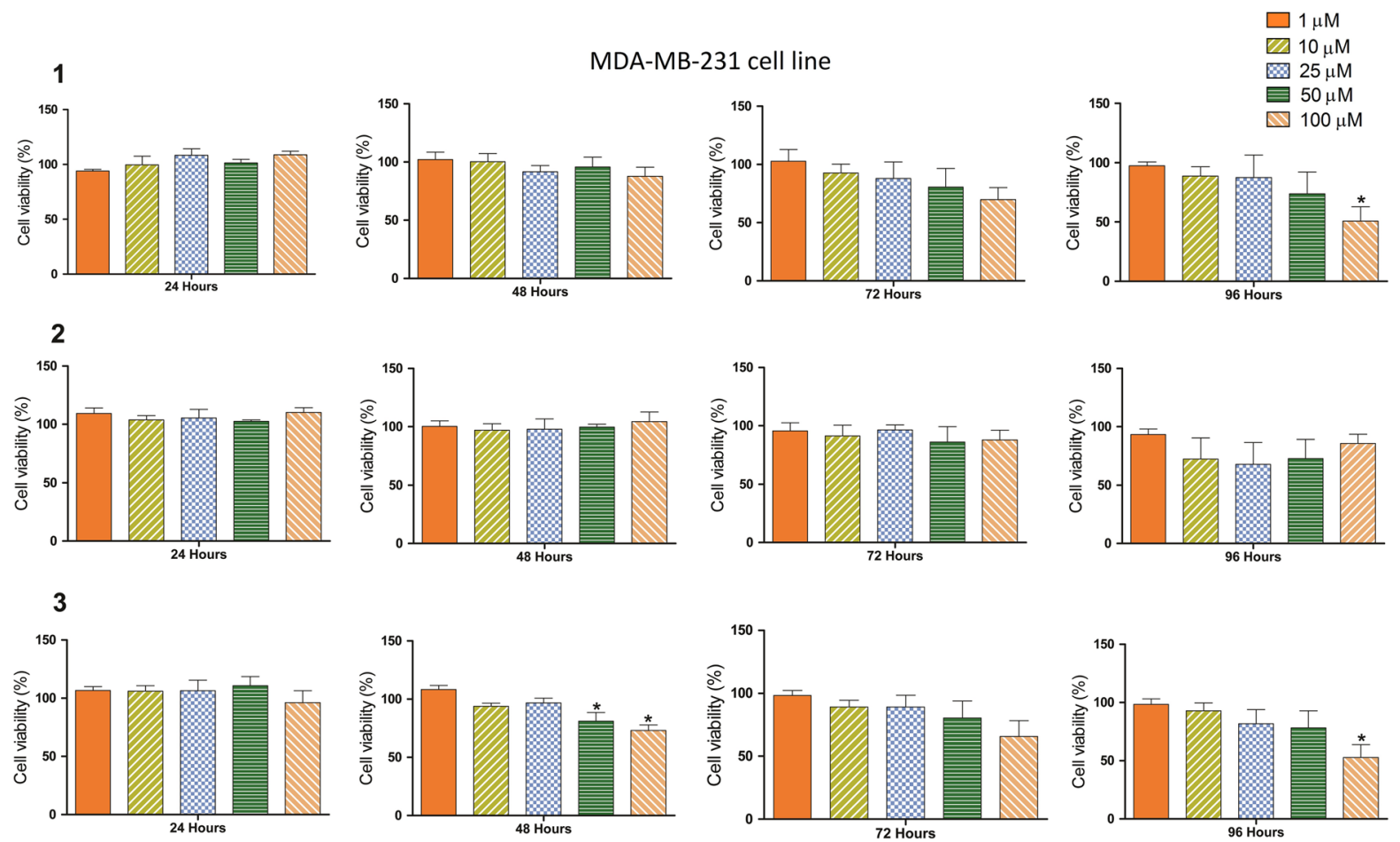

Fig. 9 Antiproliferative effect of the complex 1 and the adducts $\mathbf{2}$ and $\mathbf{3}$ against the human breast cancer MDA-MB-231 cell line for concentrations ranging from 1 to $100 \mu \mathrm{M}$ and incubation times of 24, 48, 72 and $96 \mathrm{~h}$. Cell number was analysed by using
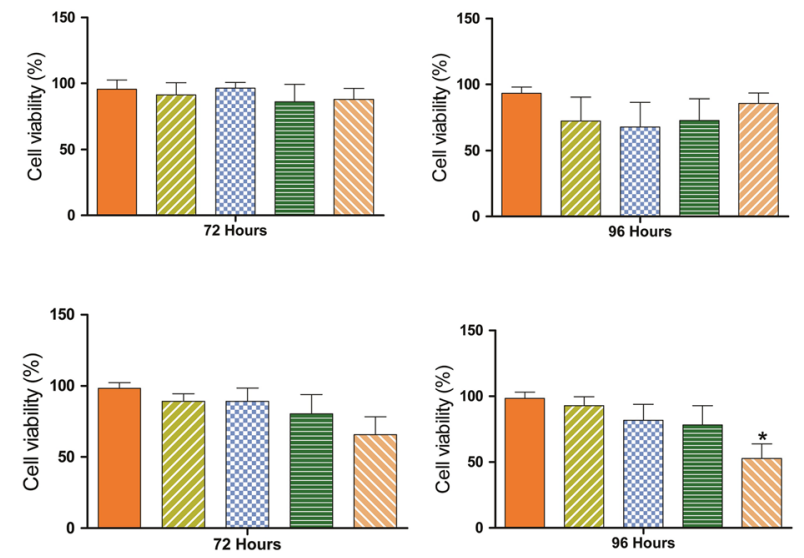

the SRB colourimetric assay. Data represent mean \pm SEM of 4 different cell preparations. The asterisk represents statistically significant growth inhibition by Dunnet's post-hoc test after one-way ANOVA (*p-value $<0.05)$

MCF-7 cells are affected by concentrations of $200 \mu \mathrm{M}$ or higher of both $\mathbf{1}$ and $\mathbf{3}$. Interestingly, and in parallel with the results observed for the MDA-MB231 cell line, inclusion into $\beta-\mathrm{CD}$ affords a slight reduction of the activity, as the cell proliferation inhibition of $\mathbf{2}$ is only significant for dosages equal to or higher than $300 \mu \mathrm{M}$. This way, the $\mathrm{IC}_{50}$ values for $\mathbf{1}$ and $\mathbf{3}$ were calculated to be ca. $260 \mu \mathrm{M}$, while for the adduct 2 a value of $315 \mu \mathrm{M}$ was obtained.

\section{Conclusion}

This report examines, for the first time, the applicability of two different carriers for the in vitro delivery of a model metal complex, $\left[\mathrm{Ru}\left([9] \mathrm{aneS}_{3}\right)(\right.$ pdon $\left.) \mathrm{Cl}\right] \mathrm{Cl}$ (1), to tumour cells. Remarkably, interaction with the carrier was best achieved when using the molecularsized carrier cyclodextrins, in particular the native $\beta-\mathrm{CD}$, which formed a true inclusion compound, $\beta-\mathrm{CD} \cdot\left[\mathrm{Ru}\left([9] \mathrm{aneS}_{3}\right)(\right.$ pdon$\left.) \mathrm{Cl}\right] \mathrm{Cl}$ (2). In turn, the

CNTs, expected to carry a large number of guest molecules per CNT unit, were unsuitable for loading the complex 1 in host-to-guest ratios adequate for biological applications and instead required high carrier concentrations, deemed unsafe for chemotherapeutic use.

The results of solid-state analysis (TGA, powder XRD and ${ }^{13} \mathrm{C}\left\{{ }^{1} \mathrm{H}\right\}$ CP/MAS NMR) of the cyclodextrin-containing products confirmed true inclusion interaction in 2 . In this compound, $\beta-\mathrm{CD}$ molecules are presumably arranged in a zig-zag cage-like mode similar to $\beta-\mathrm{CD} \cdot\left[\mathrm{Ru}\left([9] \mathrm{aneS}_{3}\right)(\right.$ phen$\left.) \mathrm{Cl}\right] \mathrm{Cl}$ (Marques et al. 2009a) as derived from the a comparative analysis of the powder diffractogram with similar reference patterns. In $\mathbf{3}$, no evidence of inclusion interactions was observed and the powder is presumed to comprise a fine dispersion of the complex 1 into an amorphous TRIMEB matrix.

The complex 1 has a moderate intercalative affinity for DNA, which may account for its cytotoxicity, as well as that of compounds $\mathbf{2}$ and $\mathbf{3}$, against mouse 
MCF-7 cell line

1

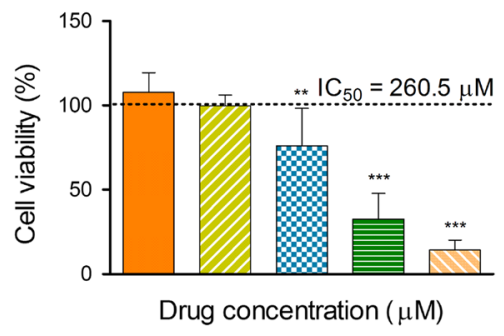

$\beta-C D$

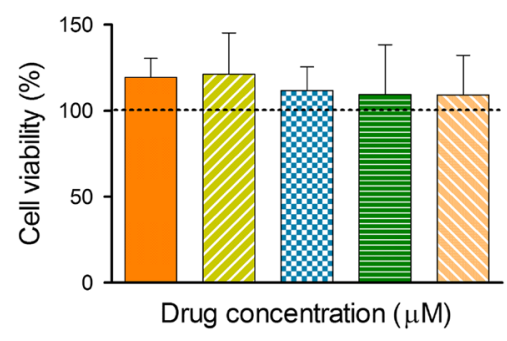

2

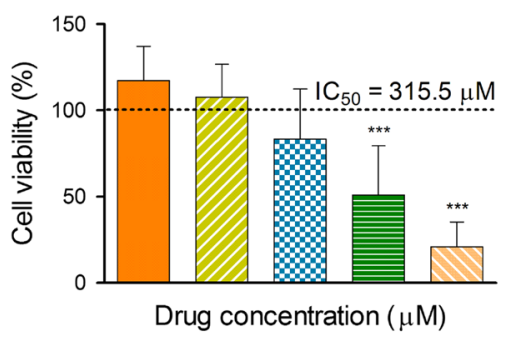

TRIMEB

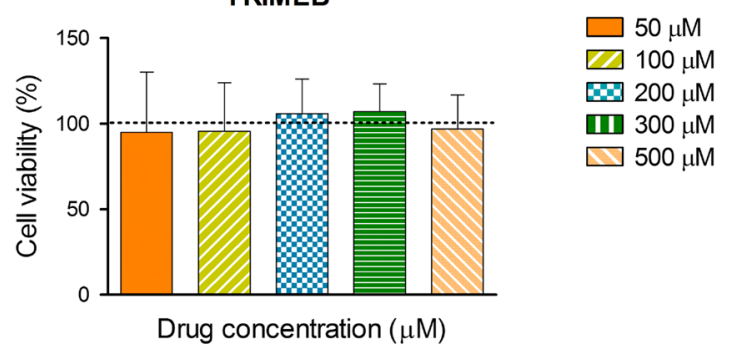

3

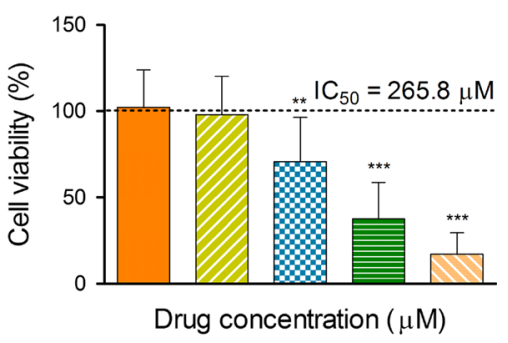

Fig. 10 Cytotoxic effect and $\mathrm{IC}_{50}$ values of the complex $\mathbf{1}$ and the adducts $\mathbf{2}$ and $\mathbf{3}$ against the human human breast cancer MCF-7 cell line at $48 \mathrm{~h}$ of incubation and concentrations ranging from 50 to $500 \mu \mathrm{M}$. Cells were also incubated with the pure hosts, $\beta$-CD and TRIMEB, to confirm their toxicological safety. Cell viability was evaluated by using the MTT assay. Data represent mean $\pm \mathrm{SD}$ of 3 different cell preparations. The asterisks represent statistically significant growth inhibition by Dunnet's post-hoc test after one-way ANOVA (** for $p$-value $<0.01$ and $* * *$ for $p$-value $<0.001$ )

incubation time of $48 \mathrm{~h}$, the $\mathrm{IC}_{50}$ determined for $\mathbf{1}$ and $\mathbf{3}$ lay around $260 \mu \mathrm{M}$.

Acknowledgments The supply of $\beta-\mathrm{CD}$ (Kleptose) by Roquette Laboratoires (Lestrem, France) is gracefully acknowledged. We are also grateful to Fundação para a Ciência e a Tecnologia (FCT, Portugal), European Union, QREN, European Fund for Regional Development (FEDER), through the programme COMPETE, for general funding to the QOPNA research unit (project PEst C-QUI/UI0062/2013; FCOMP-010124-FEDER-037296), to the Associated Laboratory CICECO (PEst C-CTM/LA0011/2013) and to the CNC (PEst-C/SAU/ LA0001/2013-2014), and for specific funding towards the purchase of the single-crystal diffractometer. The FCT and the European Social Fund, through the Programa Operacional Potencial Humano (POPH), are acknowledged for a $\mathrm{PhD}$ grant to J. M. (SFRH/BD/44791/2008).

\section{References}

Alanyali FS, Ergin E, Artagan O, Benkli K (2011) Investigation of genotoxic effects of some ruthenium complexes according to cis-platinum. Int J Pharmacol 7:96-105 
Ali-Boucetta H, Al-Jamal KT, McCarthy D, Prato M, Bianco A, Kostarelos K (2008) Multiwalled carbon nanotube-doxorubicin supramolecular complexes for cancer therapeutics. Chem Commun 4:459-461

Allen TM, Cullis PR (2004) Drug delivery systems: entering the mainstream. Science 303:1818-1822

APEX2 (2006). Data Collection Software Version 21-RC13, Bruker AXS, Delft, The Netherlands

Arlt M, Haase D, Hampel S, Oswald S, Bachmatiuk A, Klingeler R, Schulze R, Ritschel M, Leonhardt A, Fuessel S, Büchner B, Kraemer K, Wirth MP (2010) Delivery of carboplatin by carbon-based nanocontainers mediates increased cancer cell death. Nanotechol 21:335101

Barroug A, Glimcher MJ (2002) Hydroxyapatite crystals as a local delivery system for cisplatin: adsorption and release of cisplatin in vitro. J Orthop Res 20:274-280

Braga SS, Gonçalves IS, Pillinger M, Ribeiro-Claro P, TeixeiraDias JJC (2001) Experimental and theoretical study of the interaction of molybdenocene dichloride $\left(\mathrm{Cp}_{2} \mathrm{MoCl}_{2}\right)$ with $\beta$-cyclodextrin. J Organomet Chem 632:11-16

Braga SS, Gonçalves IS, Herdtweck E, Teixeira-Dias JJC (2003a) Solid state inclusion compound of S-ibuprofen in $\beta$-cyclodextrin: structure and characterization. New J Chem 27:597-601

Braga SS, Ribeiro-Claro P, Pillinger M, Gonçalves IS, Pereira F, Fernandes AC, Romão CC, Correia PB, Teixeira-Dias JJC (2003b) Encapsulation of sodium nimesulide and precursors in $\beta$-cyclodextrin. Org Biomol Chem 1:873-878

Braga SS, Ribeiro-Claro P, Pillinger M, Gonçalves IS, Fernandes $\mathrm{AC}$, Pereira F, Romão CC, Correia PB, TeixeiraDias JJC (2003c) Interactions of omeprazole and precursors with beta-cyclodextrin host molecules. J Incl Phenom Macrocycl Chem 47:47-52

Braga SS, Paz FAA, Pillinger M, Seixas JD, Romão CC, Gonçalves IS (2006) Structural studies of $\beta$-cyclodextrin and permethylated $\beta$-cyclodextrin inclusion compounds of cyclopentadienyl metal carbonyl complexes. Eur J Inorg Chem 8:1662-1669

Branco AF, Pereira SL, Moreira AC, Holy J, Sardão VA, Oliveira PJ (2011) Isoproterenol cytotoxicity is dependent on the differentiation state of the cardiomyoblast $\mathrm{H} 9 \mathrm{c} 2$ cell line. Cardiovasc Toxicol 11:191-203

Branco AF, Sampaio SF, Moreira AC, Holy J, Wallace KB, Baldeiras I, Oliveira PJ, Sardão VA (2012) Differentiationdependent doxorubicin toxicity on $\mathrm{H} 9 \mathrm{c} 2$ cardiomyoblasts. Cardiovasc Toxicol 12:326-340

Brandenburg K (1997-2010) DIAMOND, Version 32f Crystal Impact GbR, Bonn, Germany

Brechin EK, Calucci L, Englert U, Margheriti L, Pampaloni G, Pinzino C, Prescimone A (2008) 1,10-Phenanthroline-5,6dione complexes of middle transition elements: mono- and di-nuclear derivatives. Inorg Chim Acta 361:2375-2384

Bruno S, Fernandes JA, Marques J, Neto SC, Ribeiro-Claro PJ, Pillinger M, Paz FAA, Marques MPM, Braga SS, Gonçalves IS (2011) Structural studies and cytotoxicity of trimethyl(ferrocenylmethyl)ammonium iodide encapsulated in beta-cyclodextrin. Eur J Inorg Chem 32:4955-4963

Caira MR (2001) On the isostructurality of cyclodextrin inclusion complexes and its practical utility. Rev Roum Chim 46:371-386
Caira MR, Bourne SA, Mhlongo WT, Dean PM (2004) New crystalline forms of permethylated beta-cyclodextrin. Chem Commun 2004:2216-2217

Chen J-F, Ding H-M, Wang J-X, Shao L (2004) Preparation and characterization of porous hollow silica nanoparticles for drug delivery application. Biomaterials 25:723-727

Cryopad (2006). Remote monitoring and control, Version 1451, Oxford Cryosystems, Oxford, United Kingdom

Davis ME, Brewster ME (2004) Cyclodextrin-based pharmaceuticals: past, present and future. Nature Rev 3: 1023-1035

Deegan C, Coyle B, McCann M, Devereux M, Egan DA (2006) In vitro anti-tumour effect of 1,10-phenanthroline-5, 6-dione (phendione), $\left.[\mathrm{Cu} \text { (phendione) })_{3}\right]\left(\mathrm{ClO}_{4}\right)_{2} \cdot 4 \mathrm{H}_{2} \mathrm{O}$ and $\left.[\mathrm{Ag} \text { (phendione })_{2}\right] \mathrm{ClO}_{4}$ using human epithelial cell lines. Chem Biol Interact 164:115-125

Dikmen M, Benkli K, Ozturk Y (2011) Inhibition of C6 glioma cell proliferation by $\mathrm{Au}(\mathrm{III})$ and $\mathrm{Pt}(\mathrm{II})$ complexes of 1,10 phenanthroline-5,6-dione. Asian J Chem 23:2749-2754

Fernandes JA, Lima S, Braga SS, Ribeiro-Claro P, RodriguezBorges JE, Teixeira C, Pillinger M, Teixeira-Dias JJC, Gonçalves IS (2005) Inclusion complex formation of diferrocenyldimethylsilane with $\beta$-cyclodextrin. J Organomet Chem 690:4801-4808

Frodl A, Herebian D, Sheldrick WS (2002) Coligand tuning of the DNA binding properties of bioorganometallic ( $\eta^{6}$-arene) ruthenium(II) complexes of the type $\left[\left(\eta^{6}\right.\right.$-arene)-Ru(amino acid)(dppz) $]^{n+}\left(\mathrm{dppz}=\operatorname{dipyrido}\left[3,2-a: 2^{\prime}, 3^{\prime}-c\right]\right.$ phenazine $)$, $n=1-3$. J Chem Soc Dalton Trans 19:3664-3673

Goodfellow BJ, Félix V, Pacheco SMD, de Jesus JP, Drew MGB (1997) Structural characterisation of $\mathrm{Ru}(\mathrm{II})$ [9]ane $\mathrm{S}_{3}$ polypyridyl complexes by NMR spectroscopy and singlecrystal X-ray diffraction. Polyhedron 16:393-401

Goss CA, Abruña HD (1985) Spectral, electrochemical, and electrocatalytic properties of 1,10-phenanthroline-5,6dione complexes of transition metals. Inorg Chem 24:4263-4267

Guven A, Rusakova IA, Lewis MT, Wilson LJ (2012) Cisplatin@US-tube carbon nanocapsules for enhanced chemotherapeutic delivery. Biomaterials 33:1455-1461

Harada A, Saeki K, Takahashi S (1989) Preparation and properties of inclusion compounds of $\left(\eta^{6}\right.$-Arene)tricarbonylcromium $(0)$ complexes with cyclodextrins. Organometallics 8:730-733

Heister E, Lamprecht C, Neves V, Tilmaciu C, Datas L, Flahaut E, Soula B, Hinterdorfer P, Coley HM, Silva SR, McFadden J (2010) Higher dispersion efficacy of functionalized carbon nanotubes in chemical and biological environments. ACS Nano 4:2615-2626

Heister E, Neves V, Lamprecht C, Silva SR, Coley HM, McFadden J (2012) Drug loading, dispersion stability, and therapeutic efficacy in targeted drug delivery with carbon nanotubes. Carbon 50:622-632

Hilder TA, Hill JM (2008) Carbon nanotubes as drug delivery nanocapsules. Curr Appl Phys 3-4:258-261

Huang HC, Barua S, Sharma G, Dey SK, Rege K (2011) Inorganic nanoparticles for cancer imaging and therapy. J Controlled Release 155(3):344-357

Kottke T, Stalke D (1993) Crystal handling at low-temperatures. J App Cryst 26:615-619 
Kumar KA, Reddy KL, Vidhisha S, Satyanarayana S (2009) Synthesis, characterization and DNA binding and photocleavage studies of $\left[\mathrm{Ru}(\mathrm{bpy})_{2} \mathrm{BDPPZ}\right]^{2+},\left[\mathrm{Ru}(\mathrm{dmb})_{2} \mathrm{BDPPZ}\right]^{2+}$ and $\left[\mathrm{Ru}(\mathrm{phen})_{2} \mathrm{BDPPZ}\right]^{2+}$ complexes and their antimicrobial activity. Appl Organomet Chem 23:409-420

Larsson K, Öhrström L (2004) X-ray and NMR study of the fate of the $\mathrm{Co}(1,10-\text { phenanthroline-5,6-diketone })^{3+}$ ion in aqueous solution: supramolecular motifs in the packing 1,10-phenanthroline-5,6-diketone and 1,10-phenanthroline-5,6-diol complexes. Inorg Chim Acta 357:657-664

Lin FH, Lee YH, Jian CH, Wong J-M, Shieh M-J, Wang C-Y (2002) A study of purified montmorillonite intercalated with 5-fluorouracil as drug carrier. Biomaterials 23: 1981-1987

Madureira J, Santos TM, de Jesus JP, Goodfellow BJ, SantanaMarques MG, Lucena M, Drew MGB (2000) Structural characterisation of new RuII[9]aneS 3 polypyridylic complexes. J Chem Soc Dalton Trans 23:4422-4431

Marques J, Anjo L, Marques MPM, Santos TM, Paz FAA, Braga SS (2008) Structural studies on supramolecular adducts of cyclodextrins with the complex $\left[\mathrm{Ru}\left([9] \mathrm{aneS}_{3}\right)(\mathrm{bpy}) \mathrm{Cl}\right] \mathrm{Cl}$. J Organomet Chem 693:3021-3028

Marques J, Braga TM, Paz FAA, Santos TM, Lopes MFS, Braga SS (2009a) Cyclodextrins improve the antimicrobial Activity of the chloride salt of Ruthenium(II) chloro-phenanthroline-trithiacyclononane. Biometals 22:541-556

Marques J, Santos TM, Marques MPM, Braga SS (2009b) A glycine ruthenium trithiacyclononane complex and its molecular encapsulation using cyclodextrins. Dalton Trans 44:9812-9819

Mosmann T (1983) Rapid colorimetric assay for cellular growth and survival: application to proliferation and cytotoxicity assays. J Immunol Methods 65:55-63

Nakamoto K (1966) Infrared spectra of inorganic and co-ordination compounds. M. Mir, Moscow

Papazisis KT, Geromichalos GD, Dimitriadis KA, Kortsaris AH (1997) Optimization of the sulforhodamine B colorimetric assay. J Immunol Methods 208:151-158

Parveen S, Misra R, Sahoo SK (2012) Nanoparticles: a boom to drug delivery, therapeutics, diagnostics and imaging. Nanomed Nanotechnol Biol Med 8:147-166

Pereira CCL, Nolasco M, Braga SS, Paz FAA, Ribeiro-Claro P, Pillinger M, Gonçalves IS (2007) A combined theoreticalexperimental study of the inclusion of niobocene dichloride in native and permethylated $\beta$-cyclodextrins. Organometallics 26:4220-4228

Petrovski Ž, Braga SS, Rodrigues SS, Pereira CCL, Gonçalves IS, Pillinger M, Freire C, Romão CC (2005a) Synthesis of ferrocenyldiimine metal carbonyl complexes and an investigation of the Mo adduct encapsulated in cyclodextrin. New J Chem 29:347-354

Petrovski Ž, Braga SS, Santos AM, Rodrigues SS, Gonçalves IS, Pillinger M, Kühn FE, Romão CC (2005b) Synthesis and characterization of the inclusion compound of a ferrocenyldiimine dioxomolybdenum complex with heptakis2,3,6-tri- $O$-methyl-beta-cyclodextrin. Inorg Chim Acta 358:981-988
Radin S, Ducheyne P, Kamplain T, Tan BH (2001) Silica solgel for the controlled release of antibiotics. I. Synthesis, characterization, and in vitro release. J Biomed Mater Res 57:313-320

Ramos AI, Braga TM, Silva P, Fernandes JA, Ribeiro-Claro P, Lopes MFS, Paz FAA, Braga SS (2012) Chloramphenicol-cyclodextrin inclusion compounds: co-dissolution and mechanochemical preparations and antibacterial action. CrystEngComm 15:2822-2834

Roseanu A, Florian PE, Moisei E, Sima LE, Evans RW, Trif M (2010) Liposomalization of lactoferrin enhanced its antitumoral effects on melanoma cells. Biometals 23:485-492

Roy I, Ohulchanskyy TY, Pudavar HE, Bergey EJ, Oseroff AR, Morgan J, Dougherty TJ, Prasad PN (2003) Ceramic-based nanoparticles entrapping water-insoluble photosensitizing anticancer drugs: a novel drug-carrier system for photodynamic therapy. J Am Chem Soc 125:7860-7865

Roy S, Hagen KD, Maheswari PU, Lutz M, Spek AL, Reedijk J, van Wezel GP (2008) Phenanthroline derivatives with improved selectivity as DNA-targeting anticancer or antimicrobial drugs. ChemMedChem 3:1427-1434

SAINT+ (1997-2005). Data Integration Engine v 723a (C):Bruker AXS, Madison, Wisconsin, USA

Santos TM, Madureira J, Goodfellow BJ, Drew MGB, de Jesus JP, Félix V (2001) Interaction of Ruthenium(II)-dipyridophenazine complexes with CT-DNA: effects of the polyhioether ancillary ligands. Met Based-Drugs 8:125-135

Sardão VA, Oliveira PJ, Holy J, Oliveira CR, Wallace KB (2009) Doxorubicin-induced mitochondrial dysfunction is secondary to nuclear p53 activation in $\mathrm{H} 9 \mathrm{c} 2$ cardiomyoblasts. Cancer Chemother Pharmacol 64:811-827

Sheldrick GM (1997a) SHELXS-97, Program for Crystal Structure Solution, University of Göttingen

Sheldrick GM (1997b) SHELXL-97, Program for Crystal Structure Refinement, University of Göttingen

Sheldrick GM (1998) SADABS v201, Bruker/Siemens Area Detector Absorption Correction Program, Bruker AXS, Madison, WI, USA

Sheldrick GM (2008) A short history of SHELX. Acta Cryst A 64:112-122

Skehan P, Storeng R, Scudiero D, Monks A, McMahon J, Vistica D, Warren JT, Bokesch H, Kenney S, Boyd MR (1990) New colorimetric cytotoxicity assay for anticancer-drug screening. J Natl Cancer Inst 82:1107-1112

Spek AL (1990) PLATON. Acta Cryst A 46:C34

Spek AL (2003) Single-crystal structure validation with the program PLATON. J Appl Crystallogr 36:7-13

Szejtli J (1998) Cyclodextrin and general overview of cyclodextrin chemistry. Chem Rev 98:1743-1754

van der Sluis P, Spek AL (1990) Acta Cryst A 46:194-201

Wagner A, Vorauer-Uhl K (2011) Liposome technology for industrial purposes. J Drug Deliv 2011:591325. doi:10. 1155/2011/591325

Wu W, Wieckowski S, Pastorin G, Benincasa M, Klumpp C, Briand J-P, Gennaro R, Prato M, Bianco A (2005) Targeted delivery of amphotericin $\mathrm{B}$ to cells by using functionalized carbon nanotubes. Angew Chem Int Ed 44:6358-6362 